\title{
Characterization and Treatment Technologies Applied for Produced Water in Qatar
}

\author{
Hana D. Dawoud, Haleema Saleem, Nasser Abdullah Alnuaimi and Syed Javaid Zaidi *
}

check for updates

Citation: Dawoud, H.D.; Saleem, H.; Alnuaimi, N.A.; Zaidi, S.J. Characterization and Treatment Technologies Applied for Produced Water in Qatar. Water 2021, 13, 3573. https://doi.org/10.3390/w13243573

Academic Editors: Martin Wagner and Sonja Bauer

Received: 7 November 2021

Accepted: 10 December 2021

Published: 13 December 2021

Publisher's Note: MDPI stays neutral with regard to jurisdictional claims in published maps and institutional affiliations.

Copyright: (c) 2021 by the authors. Licensee MDPI, Basel, Switzerland. This article is an open access article distributed under the terms and conditions of the Creative Commons Attribution (CC BY) license (https:// creativecommons.org/licenses/by/ $4.0 /)$.

\author{
Center for Advanced Materials, Qatar University, P.O. Box 2713, Doha 2713, Qatar; \\ hanadawoud@qu.edu.qa (H.D.D.); haleema.saleem@qu.edu.qa (H.S.); anasser@qu.edu.qa (N.A.A.) \\ * Correspondence: szaidi@qu.edu.qa
}

\begin{abstract}
Qatar is one of the major natural gas (NG) producing countries, which has the world's third-largest NG reserves besides the largest supplier of liquefied natural gas (LNG). Since the produced water (PW) generated in the oil and gas industry is considered as the largest waste stream, cost-effective PW management becomes fundamentally essential. The oil/gas industries in Qatar produce large amounts of PW daily, hence the key challenges facing these industries reducing the volume of PW injected in disposal wells by a level of 50\% for ensuring the long-term sustainability of the reservoir. Moreover, it is important to study the characteristics of PW to determine the appropriate method to treat it and then use it for various applications such as irrigation, or dispose of it without harming the environment. This review paper targets to highlight the generation of PW in Qatar, as well as discuss the characteristics of chemical, physical, and biological treatment techniques in detail. These processes and methods discussed are not only applied by Qatari companies, but also by other companies associated or in collaboration with those in Qatar. Finally, case studies from different companies in Qatar and the challenges of treating the PW are discussed. From the different studies analyzed, various techniques as well as sequencing of different techniques were noted to be employed for the effective treatment of PW.
\end{abstract}

Keywords: produced water treatment; produced water characterization; Qatar

\section{Introduction}

Produced water (PW), or oilfield wastewater, are terms used to describe the water produced from oil and gas industries in the extraction process [1,2]. It contains brine, as well as a combination of various organic and inorganic compounds [3]. Remarkably, the volume of wastewater all over the world is increasing, which leads to significant attention of the harmful effects of discharging PW on the environment [4,5]. Moreover, this discharge causes a polluted surface in underground water as well as in soil [6]. It is important to mention that the oil extraction process is a physical process consisting of different individual steps [7]. Initially, the oil is extracted by drilling the oil reservoir using subsea pipelines. In this process, the oil, gases, and water from seawater are extracted [8]. To achieve maximum oil recovery and sustain the pressure of the reservoir, two techniques are employed $[9,10]$. The first technique is water flooding or water injection, in which water is injected into the reservoirs for the purpose of adding extra force into the reservoir [11,12]. The injected water ultimately reaches the reservoirs, and in the later stages of water-injection, the produced water proportion leads to the production of more oil and recovery of the lost pressure in the reservoir due to oil extracting [13]. The second technique is gas flooding or gas injection, where the gas must improve the lifting of the fluid from the reservoir to the manifolds, which aids in reducing the density of the extracted fluid $[14,15]$. Nonetheless, due to the generation of a large volume of produced water from oil/gas fields in Qatar, different treatments are applied to treat this PW in an efficient and economical way [16]. Currently, there are different technologies used for the purification of wastewater [17-20], and the treatment methods are divided into chemical treatment [21,22], physical treatment [23-25], and biological 
treatment. Physical treatment includes gravity separation and adsorption [26,27], usage of hydrocyclones separator, membrane filtration-based techniques (sand filtration, membrane distillation, ceramic membranes, membrane bioreactors, hybrid, and asymmetric membranes), application of hydrate inhibitors, demulsification, coalescing, thermal evaporators, forward osmosis, etc. [28-33]. Moreover, chemical treatments consist of photocatalytic treatment, chemical oxidation, chemical precipitation, electrochemical process, Fenton process, treatment with ozone, demulsifiers, and room temperature ionic liquids [34-36]. Presently, the membrane treatment processes such as nanofiltration (NF), ultrafiltration (UF), microfiltration (MF), and reverse osmosis $(\mathrm{RO})$ are gaining importance in reducing the contamination from PW [37]. The biological treatment of produced water is efficient; however, it is rarely utilized for the oil- and gas-produced water [38]. Some of the most commonly used biological treatment configurations were fixed-film treatment, membrane bioreactors, and constructed wetlands and ponds. The fixed-film reactors consisted of tanks covered with higher-surface area media, rotating biological contactors, and granular activated carbon filters, as well as aerobic filters. Table 1 presents the summary of different produced water treatment technologies [39-41]. Table 2 presents the commercial treatment processes worldwide.

Table 1. Summary of different produced water treatment technologies [39-41].

\begin{tabular}{|c|c|c|}
\hline $\begin{array}{l}\text { Treatment } \\
\text { Technologies }\end{array}$ & Advantages & Disadvantages \\
\hline $\begin{array}{l}\text { Membrane } \\
\text { separation }\end{array}$ & $\begin{array}{l}\text { 1. Removal of dissolved organic substances could } \\
\text { be achieved by selecting } \\
\text { an appropriate membrane. } \\
\text { 2. Advanced purification. } \\
\text { 3. Have separation impacts on suspended solids. }\end{array}$ & $\begin{array}{l}\text { 1. Pollution chances are high. Hence, backwashing } \\
\text { is needed. } \\
\text { 2. Polymer membrane degrades at higher } \\
\text { temperature (greater than } 50^{\circ} \mathrm{C} \text { ). The } \mathrm{PW} \\
\text { temperature is generally greater than } 50^{\circ} \mathrm{C} \text {. }\end{array}$ \\
\hline $\begin{array}{l}\text { Combined fiber } \\
\text { coalescence }\end{array}$ & $\begin{array}{l}\text { 1. It can handle PW with higher oil content. } \\
\text { 2. The suspend solids could penetrate the fiber } \\
\text { module with no blockage. }\end{array}$ & $\begin{array}{l}\text { 1. Solid particles having millimeter-scale dimensions } \\
\text { can cause blockage. } \\
\text { 2. Fiber parameters can influence the separation } \\
\text { efficiency. The device must be designed as per the } \\
\text { PW characteristics. }\end{array}$ \\
\hline $\begin{array}{l}\text { Tubular } \\
\text { separation }\end{array}$ & 1. Small and could be fixed under water. & $\begin{array}{l}\text { 1. The anti-fluctuation performance as a pretreatment } \\
\text { should be proved. }\end{array}$ \\
\hline Media filtration & $\begin{array}{l}\text { 1. Advanced purification. } \\
\text { 2. Demonstrates separation effects on } \\
\text { suspended solids. }\end{array}$ & $\begin{array}{l}\text { 1. Pollution chances are high. Hence, backwashing } \\
\text { is needed. } \\
\text { 2. The influent must not have higher oil content. } \\
\text { 3. Media replacement is required. }\end{array}$ \\
\hline Hydrocyclone & $\begin{array}{l}\text { 1. Compact with no moving parts. } \\
\text { 2. Can handle PW with higher oil content. }\end{array}$ & $\begin{array}{l}\text { 1. Limited range of higher efficiency } \\
\text { operation region. } \\
\text { 2. Separation effects are influenced by blockage as } \\
\text { well as the wear of one or more cyclone tubes. }\end{array}$ \\
\hline $\begin{array}{l}\text { Gravity and } \\
\text { enhanced } \\
\text { gravity } \\
\text { sedimentation }\end{array}$ & $\begin{array}{l}\text { 1. Anti-fluctuation ability of the gas } \\
\text { concentration, oil content, and flow rate. } \\
\text { 2. Essential pretreatment device having extensive } \\
\text { operation flexibility. } \\
\text { 3. Easy equipment with minimal operational } \\
\text { expenses and maintenance needs. }\end{array}$ & $\begin{array}{l}\text { 1. Higher occupation of space resulting from the } \\
\text { separation mechanism. } \\
\text { 2. Lower separation accuracy. }\end{array}$ \\
\hline
\end{tabular}


Table 2. Commercial treatment processes worldwide.

\begin{tabular}{|c|c|c|c|c|}
\hline Technology & Commercial System & Treatments & Water Recovery & Reference \\
\hline Reverse Osmosis & CDM Technology & $\begin{array}{c}\text { Combination of } 3 \text { major processes } \\
\text { such as ion exchange process, } \mathrm{RO} \text {, and } \\
\text { evaporation }\end{array}$ & $50-90 \%$ & {$[40]$} \\
\hline Reverse Osmosis & Veolia:OPUSTM & $\begin{array}{l}\text { Acidification, Degasification and } \\
\text { followed by MultifloTM chemical } \\
\text { softening and Reverse Osmosis }\end{array}$ & Higher than $90 \%$ & {$[41]$} \\
\hline Reverse Osmosis & Eco-sphere: OzonixTM & $\begin{array}{l}\text { Activated carbon cartridge filtration } \\
\text { and RO }\end{array}$ & $75 \%$ & {$[40]$} \\
\hline Reverse Osmosis & $\begin{array}{l}\text { GeoPure water } \\
\text { technologies }\end{array}$ & $\begin{array}{l}\text { Combination of pretreatment, UF and } \\
\text { RO }\end{array}$ & $50 \%$ & {$[40]$} \\
\hline $\begin{array}{l}\text { Ion-Exchange (IX) } \\
\text { based processes }\end{array}$ & EMIT: Higgins Loop & $\begin{array}{l}\text { Continuous counter current ion } \\
\text { exchange contactor for liquid phase } \\
\text { separations of ionic components. }\end{array}$ & $99 \%$ & [37] \\
\hline $\begin{array}{l}\text { Ion-Exchange (IX) } \\
\text { based processes }\end{array}$ & $\begin{array}{l}\text { Drake: Continuous } \\
\text { selective IX process }\end{array}$ & $\begin{array}{l}\text { 3-phase, continuous fluidized bed } \\
\text { system }\end{array}$ & $97 \%$ & [40] \\
\hline $\begin{array}{l}\text { Ion-Exchange (IX) } \\
\text { based processes }\end{array}$ & $\begin{array}{c}\text { Eco-Tech: Recoflo }{ }^{\circledR} \\
\text { compressed-bed IX process }\end{array}$ & $\begin{array}{c}\text { Extension of standardpacked bed IX } \\
\text { processes }\end{array}$ & - & [40] \\
\hline
\end{tabular}

During the COVID-19 crisis, the worldwide market for PW treatment was assessed to be USD 8.1 billion in the year 2020, and is expected to achieve a revised size of USD 11.2 billion by the year 2027, increasing at a compound annual growth rate of $4.8 \%$ over the assessment period 2020-2027 [42]. The PW treatment market in the United States of America is estimated at USD 2.2 billion in 2020. In Qatar, value oil production in the year 2020 was 1343.14 thousand barrels/day, relative to 1550 thousand barrels/day in 2011 [43]. This clearly confirmed the increase in the production volume of produced water also.

Treated produced water can be reused in various applications, such as in increasing oil production by underground injection, irrigation, livestock, or wildlife watering, and various industrial uses (e.g., fire control, vehicle washing, dust control, and power plant makeup water) $[41,44,45]$. Adopting various treatment technologies is important to assess the adverse environmental impacts, as well as to reach the standards demanded reinjection, reusing, and discharging the PW [46]. All of these will support a harmless release or reinjection of PW in plant irrigation to share in the sustainability of the Qatar environment $[47,48]$.

In this paper, a comprehensive review of produced water generated and treated in Qatar is attempted. To the best of our knowledge, there are very few studies discussing this topic. Since the focus in this paper is on PW, three areas will be highlighted through the review: characterization of produced water; treatments methods, challenges and future developments related to using efficient treatment technology; and cost-effectiveness of treating produced water. The main aim of the current review paper is to promote the appropriate characterization and treatment of PQ in Qatar for reducing the dependence on the very limited freshwater resources. All of the available data in the open literature related to PW in Qatar are summarized and presented in Table 3. 
Table 3. Comparison of treatment methods, characterizations, and applications of produced water from different entities in Qatar.

\begin{tabular}{|c|c|c|c|c|c|c|c|}
\hline Sl. No. & Treatments Used & Methods Used & Merits/Demerits & Main Characterization & $\begin{array}{l}\text { PW Characteristics/Target } \\
\text { Contaminants Removed }\end{array}$ & Significance of the Study & References \\
\hline 1 & $\begin{array}{l}\text { Membrane processes (UF, NF, and } \\
\text { RO), thermal evaporations and } \\
\text { advanced oxidation process }\end{array}$ & Membrane-based & - & TDS, COD, KHI, salinity, conductivity & $\begin{array}{c}\text { Monovalent and divalent ions } \\
\text { (Calcium, magnesium, potassium) }\end{array}$ & PW use in irrigation & [49] \\
\hline 2 & Forward osmosis & Membrane-based & $\begin{array}{l}\text { FO offers ecofriendly dilution } \\
\text { before discharge. }\end{array}$ & $\begin{array}{l}\mathrm{pH}, \mathrm{TOC}, \mathrm{TC}, \text { inorganic carbon, water flux, } \\
\text { anion and cations, ions, metals, salinity, } \\
\text { organic and inorganic contents }\end{array}$ & $\begin{array}{l}\text { Inorganic carbons, Monovalent } \\
\text { and divalent ions }\end{array}$ & Efficiency of FO process & {$[50]$} \\
\hline 3 & $\begin{array}{l}\text { Hollow Fiber Forward Osmosis } \\
\text { Membranes }\end{array}$ & Membrane-based & $\begin{array}{l}\text { FO process leads to } \\
\text { environmentally friendly } \\
\text { dilution before discharge }\end{array}$ & $\begin{array}{l}\text { Conductivity, } \mathrm{pH} \text {, anion and cation, TDS, } \\
\text { TN, TOC, IC, and osmotic pressure }\end{array}$ & $\begin{array}{c}\text { Chloride, sodium, calcium, } \\
\text { magnesium, bromide, sulfate, } \\
\text { potassium, phosphate, TOC, TN }\end{array}$ & Efficiency of FO process & [51] \\
\hline 4 & Membrane bioreactors (MBRs) & Membrane-based & $\begin{array}{l}\text { Economical and good } \\
\text { separation performance }\end{array}$ & $\begin{array}{l}\text { COD, conductivity, pH TSS, VSS, TN, TPH, } \\
\text { TOG, DO, and TOC }\end{array}$ & $\begin{array}{l}\text { Organic carbons, potassium, } \\
\text { ammonium, phosphate }\end{array}$ & Efficiency of MBRs & {$[52]$} \\
\hline 5 & $\begin{array}{c}\text { Forward osmosis membranes sing } \\
\text { thin-film composite FO hollow } \\
\text { fiber membranes }\end{array}$ & Membrane-based & $\begin{array}{l}\text { FO process leads to } \\
\text { environmentally friendly } \\
\text { dilution before discharge }\end{array}$ & $\begin{array}{l}\text { TDS, TOC, inorganic carbon, conductivity, } \\
\text { alkalinity, turbidity, } \mathrm{pH}\end{array}$ & Organic carbons & $\mathrm{PW}$ use in irrigation & {$[53]$} \\
\hline 6 & MBRs & Membrane-based & $\begin{array}{l}\text { Economical and good } \\
\text { separation performance }\end{array}$ & $\begin{array}{l}\text { COD, TOC, TN, anion and cation, oil and } \\
\text { grease, TPH, thiosulfate, conductivity }\end{array}$ & $\begin{array}{c}\text { Anion and cation, oil and grease, } \\
\text { TPH, thiosulfate }\end{array}$ & Efficiency of MBRs & [54] \\
\hline 7 & $\begin{array}{l}\text { Membrane processes, } \\
\text { membrane bioreactors, } \\
\text { membrane distillation } \\
\text { and ozonation }\end{array}$ & Membrane-based & $\begin{array}{l}\text { Economical and good } \\
\text { separation performance }\end{array}$ & $\begin{array}{l}\text { TDS, COD, KHI, salinity, conductivity, ions, } \\
\text { and cations }\end{array}$ & Cations, TDS & $\begin{array}{l}\text { Efficiency of MB process, MD, } \\
\text { ozonation, and membrane } \\
\text { bioreactors }\end{array}$ & [55] \\
\hline 8 & Membrane distillation & Membrane-based & & $\begin{array}{l}\text { TDS, DOC, TOC, COD, conductivity, } \\
\text { phenol, oil and grease }\end{array}$ & Grease, oil, phenol & MD efficiency for PW treatment & [56] \\
\hline 10 & $\begin{array}{l}\text { Crossflow multi-channel ceramic } \\
\left.\text { membrane ( } \mathrm{TiO}_{2} \text { and } \mathrm{SiC}\right)\end{array}$ & Membrane-based & $\begin{array}{l}\text { Permits produced water } \\
\text { re-Injection even in difficult } \\
\text { reservoirs with no loss } \\
\text { in injectivity }\end{array}$ & $\begin{array}{l}\mathrm{pH} \text {, conductivity, sulphide, TS, TOC, } \\
\text { hardness, iron, } \mathrm{O} \text { and } \mathrm{G}\end{array}$ & Iron, oil, grease & $\begin{array}{c}\text { Membrane process effectiveness } \\
\text { in PW treatment }\end{array}$ & [58] \\
\hline 11 & $\begin{array}{l}\text { Chemical cleaning in place (CIP) } \\
\text { between ceramic membrane }\end{array}$ & Membrane-based & & $\begin{array}{l}\mathrm{pH} \text {, calcium, barium, and iron alkaline, oil } \\
\text { and inorganic reagents, turbidity and oil } \\
\text { and grease }\end{array}$ & $\begin{array}{l}\text { Oil, grease, calcium, barium, } \\
\text { inorganic reagents }\end{array}$ & $\begin{array}{l}\text { Ceramic microfiltration } \\
\text { membrane }\end{array}$ & [59] \\
\hline 12 & Ceramic membrane & Membrane-based & $\begin{array}{l}\text { Permits produced water } \\
\text { re-Injection even in difficult } \\
\text { reservoirs wit no loss } \\
\text { in injectivity }\end{array}$ & $\begin{array}{l}\text { Particulate solids, Feed and permeate oil } \\
\text { concentration, TOC, COD, turbidity }\end{array}$ & $\begin{array}{l}\text { Organic carbons and } \\
\text { suspended solids }\end{array}$ & $\begin{array}{l}\text { Crossflow ceramic microfiltration } \\
\text { (CFCMF) to the removal of } \\
\text { emulsified oil } \\
\text { produced water }\end{array}$ & {$[60]$} \\
\hline 13 & $\begin{array}{c}\text { Hybrid Separator-Adsorbent } \\
\text { Inorganic Membrane }\left(\mathrm{Al}_{2} \mathrm{O}_{3}\right. \\
\text { and } \mathrm{AC})\end{array}$ & Membrane-based & & Salinity, oil removal efficiency, water flux & Oil removal, Salt removal & $\begin{array}{l}\text { Inorganic Membrane for } \\
\text { PW management }\end{array}$ & [61] \\
\hline
\end{tabular}


Table 3. Cont

\begin{tabular}{|c|c|c|c|c|c|c|c|}
\hline S1. No. & Treatments Used & Methods Used & Merits/Demerits & Main Characterization & $\begin{array}{l}\text { PW Characteristics/Target } \\
\text { Contaminants Removed }\end{array}$ & Significance of the Study & References \\
\hline 14 & $\begin{array}{l}\text { Crossflow membrane filtration } \\
\text { (CMF), media } \\
\text { (nutshell) filtration (NSF induced } \\
\text { gas flotation (IGF), and } \\
\text { Hydrocyclones (HCs) }\end{array}$ & Membrane-based & & $\begin{array}{l}\text { Efficiency of removing the } \\
\text { suspended matters- }\end{array}$ & Suspended matters removal & $\begin{array}{l}\text { application of an effective } \\
\text { chemical clean }\end{array}$ & [62] \\
\hline 15 & $\begin{array}{l}\text { Hydrogel Forward Osmosis } \\
\text { Membrane }\end{array}$ & Membrane-based & $\begin{array}{l}\text { FO process leads to } \\
\text { environmentally friendly } \\
\text { dilution before discharge }\end{array}$ & TOC & Organic carbons, oil and grease & $\begin{array}{l}\text { Efficiency of FO process for } \\
\text { PW treatment }\end{array}$ & [63] \\
\hline 16 & $\begin{array}{l}\text { Biotreatment of Hydrate-Inhibitor } \\
\text { with activated sludge process }\end{array}$ & Membrane-based & $\begin{array}{l}\text { Most economical approach } \\
\text { for organics removal }\end{array}$ & $\begin{array}{l}\text { Ammonium, phosphate, potassium, COD, } \\
\text { conductivity, pH TSS, VSS, TN, TPH, TOG, } \\
\text { DO and TOC }\end{array}$ & $\begin{array}{l}\text { Organic carbons, Ammonium, } \\
\text { phosphate, potassium }\end{array}$ & $\mathrm{PW}$ use in irrigation & {$[64]$} \\
\hline 17 & $\begin{array}{l}\text { Flocculation flotation unit, } \\
\text { biotreatment, membrane filtration } \\
\text { (UF, RO units), evaporation and } \\
\text { crystallization processes }\end{array}$ & Membrane-based & $\begin{array}{l}\text { Permits produced water } \\
\text { re-Injection even in difficult } \\
\text { reservoirs with no loss } \\
\text { in injectivity }\end{array}$ & $\begin{array}{c}\mathrm{pH} \text {, conductivity, TOC, ion } \\
\text { chromatography, metal, COD, TDS, Ca, Mg, } \\
\text { Ba and heavy metal }\end{array}$ & $\begin{array}{l}\text { Heavy metals, organic carbons, } \\
\text { dissolved solids, divalent ions }\end{array}$ & $\begin{array}{l}\text { Cooling and power generation } \\
\text { among different uses }\end{array}$ & [65] \\
\hline 18 & $\begin{array}{l}\text { Coagulation, dissolved air } \\
\text { flotation and } \\
\text { Evaporation technology }\end{array}$ & Coagulation & Energy saving process & $\begin{array}{l}\text { COD, KHI, ions and cations, Total hardness, } \\
\text { TKN, TOC, O and G, TSS, Cl, TDS }\end{array}$ & Grease, oil, organic carbons & $\begin{array}{l}\text { Removal of KHI } \\
\text { co-polymers application }\end{array}$ & {$[66]$} \\
\hline 19 & Electrocoagulation & Coagulation & $\begin{array}{l}\text { Highly efficient and energy } \\
\text { saving process }\end{array}$ & $\begin{array}{c}\text { Ammonium, phosphate, potassium, COD, } \\
\text { conductivity, cations and anions, } \\
\text { ionic-liquid, pH TSS, VSS, TN, TPH, TOG, } \\
\text { DO and TOC }\end{array}$ & $\begin{array}{l}\text { Phosphate, potassium, } \\
\text { organic carbons }\end{array}$ & $\begin{array}{l}\text { Efficiency of electrocoaguation for } \\
\text { PW treatment }\end{array}$ & [67] \\
\hline 21 & Electrocoagulation and steel slag & Coagulation & Energy saving process & Oil and grease removal, turbidity, TSS & Suspended solids, oil and grease & $\begin{array}{c}\text { Efficiency of electrocoagulation } \\
\text { and steel slag } \\
\text { for PW treatment }\end{array}$ & [69] \\
\hline 22 & - & Biological treatment & $\begin{array}{l}\text { Produces huge amount of } \\
\text { biomass that could be } \\
\text { employed as feedstock for } \\
\text { many products }\end{array}$ & Bacterial colony-forming units (CFU) & $\begin{array}{l}\text { Chloride, sulfate, bromide, } \\
\text { sodium, magnesium, calcium, and } \\
\text { potassium, strontium and boron }\end{array}$ & $\begin{array}{l}\text { 1-Irrigation of } 2 \text { turfgrass } \\
\text { species, Paspalum sp. and } \\
\text { Cynodon dactylon. } \\
\text { 2-Studying the impact of PW } \\
\text { irrigation on established grasses, } \\
\text { heavy metal accumulation, } \\
\text { microbial succession, and } \\
\text { germination tests for weeds and } \\
\text { turf grass seeds }\end{array}$ & [70] \\
\hline 23 & Microalgae strains & Biological treatment & $\begin{array}{l}\text { Most economical approach } \\
\text { for organics removal. }\end{array}$ & $\begin{array}{l}\text { Salinity, } \mathrm{pH} \text {, } \\
\text { TOC, TN, TP }\end{array}$ & Salts, phosphorus & Use of biomass as feedstock & [71] \\
\hline 24 & $\begin{array}{c}\text { Microscopic microalgae; } \\
\text { screening, } 5 \text { species of microalgae } \\
\text { strains Dictyosphaerium, } \\
\text { Scenedesmus, Chlorella, } \\
\text { Monoraphidium, Neochloris. }\end{array}$ & Biological treatment & $\begin{array}{l}\text { Most economical approach } \\
\text { for organics removal. }\end{array}$ & $\begin{array}{l}\text { TP, BTEX, Fe, Al, TOC, TN, COD, TKN, } \\
\text { turbidity, salinity, pH, and ammonium }\end{array}$ & $\begin{array}{l}\text { Organic carbons, phosphorus, } \\
\text { salts, ammonium }\end{array}$ & $\begin{array}{l}\text { Application of microalgae for } \\
\text { PW treatment }\end{array}$ & [72] \\
\hline
\end{tabular}


Table 3. Cont.

\begin{tabular}{|c|c|c|c|c|c|c|c|}
\hline Sl. No. & Treatments Used & Methods Used & Merits/Demerits & Main Characterization & $\begin{array}{l}\text { PW Characteristics/Target } \\
\text { Contaminants Removed }\end{array}$ & Significance of the Study & References \\
\hline 25 & $\begin{array}{l}\text { Five microalgae strains used for } \\
\text { water treatment: Monoraphidium, } \\
\text { Chlorella, Neochloris, Scenedesmus, } \\
\text { Dictyosphoerium, Chlorella and } \\
\text { Dictyosphaerium species }\end{array}$ & Biological treatment & $\begin{array}{l}\text { Most economical approach } \\
\text { for organics removal. }\end{array}$ & $\begin{array}{l}\text { Organic carbon, nitrogen removal and } \\
\text { phosphorus and various metals, removal } \\
\text { efficiencies, TOC and BTEX }\end{array}$ & $\begin{array}{l}\text { Nitrogen, metals, organic carbons, } \\
\text { phosphorus, salts, ammonium }\end{array}$ & $\begin{array}{l}\text { Application of microalgae for } \\
\text { PW treatment }\end{array}$ & [73] \\
\hline 26 & - & Biological treatment & $\begin{array}{l}\text { Most economical approach } \\
\text { for organics removal. }\end{array}$ & Salinity, bacterial and fungal CFUs & Salts and microorganisms & $\begin{array}{l}\text { Irrigation of turf } \\
\text { grass-Paspalum sp. and } \\
\text { Cynodon dactylon }\end{array}$ & [74] \\
\hline 27 & - & & & $\begin{array}{l}\text { TDS, boron, sodium, chloride ions, sodium } \\
\text { adsorption, and organic contents }\end{array}$ & $\begin{array}{l}\text { Organic compounds, boron, } \\
\text { and salt }\end{array}$ & $\begin{array}{l}\text { Plant irrigation in greenhouse for } \\
\text { Salsola baryosma, } \\
\text { Phramites australis Sorghum bicolor, } \\
\text { Medicago sativa, Helianthus annus } \\
\text { and Zea mays }\end{array}$ & [75] \\
\hline 28 & $\begin{array}{l}\text { Sand filtration activated carbon } \\
\text { filtration (ACF) as well as } \\
\text { modified activated } \\
\text { carbon filtration. }\end{array}$ & $\begin{array}{l}\text { Activated Carbon } \\
\text { filtration }\end{array}$ & Increased removal of $\mathrm{COD}$ & $\begin{array}{l}\text { Cations, metals, inorganic anions, BTEX, } \\
\text { phenolic, organic acids, oil and grease, } \\
\text { sulfides, hardness, alkalinity, conductivity, } \\
\text { BOD, TOC, COD, and pH }\end{array}$ & $\begin{array}{l}\text { Phenolic, organic acids, oil and } \\
\text { grease, sulfides, cations, metals, } \\
\text { inorganic anions, BTEX }\end{array}$ & - & {$[76]$} \\
\hline 29 & $\begin{array}{l}\text { Activated carbon filtration and } \\
\text { microemulsions modified AC }\end{array}$ & $\begin{array}{l}\text { Activated Carbon } \\
\text { filtration }\end{array}$ & Increased removal of $\mathrm{COD}$ & $\begin{array}{c}\text { Heavy metals, salts, toxic organic } \\
\text { components, and TDS, BTEX, pH, COD, } \\
\text { TOC, TN, TDS, conductivity, alkalinity, } \\
\text { hardness and sever all metals }\end{array}$ & $\begin{array}{l}\text { Toxic organic components, heavy } \\
\text { metals, salts, dissolved solids }\end{array}$ & Irrigation application of $\mathrm{PW}$ & {$[77]$} \\
\hline 30 & $\begin{array}{l}\text { Series of inclined multiple arc } \\
\text { coalescence plates }\end{array}$ & Coalescing & - & Salinity, oil removal & Oil & $\begin{array}{l}\text { Removal of stable oil emulsions } \\
\text { from PW }\end{array}$ & [78] \\
\hline 32 & Chemical demulsification & Chemical method & - & Cations and anions, ionic liquid & Anions and cations & $\begin{array}{c}\text { Efficacy of chemical } \\
\text { demulsification for PW treatment }\end{array}$ & [80] \\
\hline 33 & $\begin{array}{c}\text { Site 1: } 2 \text { phase separation tanks } \\
\text { combined with filtration unit as } \\
\text { well as chemical injection, and } \\
\text { finally the large gravitational } \\
\text { separation tanks. } \\
\text { Site 2: begins with 2-stage } \\
\text { separation with chemical } \\
\text { injection, } 2 \text { phases succeeded by } \\
3 \text { phase separation tanks } \\
\text { combined with hydrocyclone } \\
\text { succeeded by surge drum. }\end{array}$ & Chemical method & - & $\begin{array}{l}\text { Total sulfides, dissolved } \mathrm{CO}_{2,} \text { concentration } \\
\text { of ions, phosphates, ammonia nitrogen, } \\
\text { concentration of total Kjeldahl nitrogen, } \\
\text { concentration of metals, total dissolved } \\
\text { solids, total suspended solids, } \\
\text { biodegradable COD, total COD, Phenol } \\
\text { concentration, BTEX concentration, total } \\
\text { amount of hydrocarbons, conductivity, pH, } \\
\text { and oil droplet size distribution }\end{array}$ & $\begin{array}{l}\text { Phosphates, ammonia } \\
\text { nitrogen, sulfides }\end{array}$ & - & [81] \\
\hline 34 & $\begin{array}{l}\text { Anionic polyacrylamide (PAMs) } \\
\text { with electrolyte of aluminum } \\
\text { sulphate and ferrous sulphate }\end{array}$ & Chemical method & - & Turbidity, viscosity, and COD & & - & [82] \\
\hline
\end{tabular}




\section{Methodology for the Literature Review}

Figure 1 presents the number of articles (by year), where the expression 'produced water Qatar' was found in the title, abstract, or keywords, in the last 10 years. This figure was created from scopus.com (accessed on 5 December 2021). The database showed 96 total studies, with eight studies in 2021 (reported until December), and only four studies during 2012. The entire studies were published from 1993 to 2021. There is a slow growth in studies based on produced water noted in Qatar in the past ten years. Of the different studies, the majority studies were based on the membrane-based PW treatment processes such as membrane distillation, forward osmosis, reverse osmosis, etc. Studies were considered in this work only if the water studied represented produced water. Different project motives were identified by the study authors, even though environmental challenge was the most predominant. It was highly evident from the research works that scientists are interested in the beneficial reusing as well as recycling of PW. The majority of the PW samples were obtained from oilfields, although a few PW samples were obtained from gas production wells.

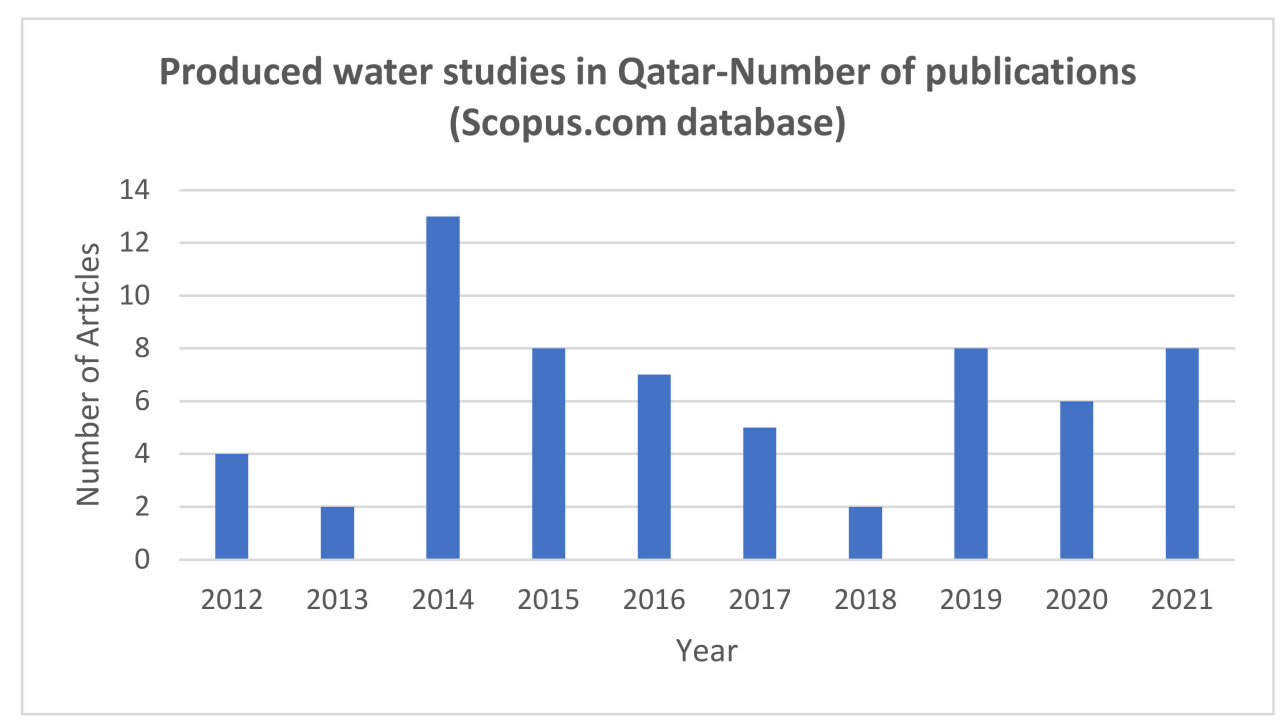

Figure 1. The number of articles (by year), where the expression 'produced water Qatar' was found in the title, abstract, or keywords, in the last 10 years. Data extracted from the scopus.com database (5 December 2021).

\section{Produced Water in Qatar}

Due to the increasing demand for fresh water, there is a need to develop new water sources in Qatar. With appropriate treatment of PW, it can serve as a new water supply in Qatar. There are three main sources of PW, namely aquifer, formation, and injection water [81]. PW quality varies significantly from field to field, but generally, the total dissolved solids concentration can range from a few thousand to over 400,000 $\mathrm{mg} / \mathrm{L}$ [83]. It is worth mentioning that the PW produced from the NG production system in the north field offshore is counted as the major volume of wastewater in Qatar, and this could be used for beneficial applications. This water source from the industry can be used for domestic uses if it is treated properly $[84,85]$.

The global estimation of PW production is approximately 250 million barrels per day, relative to a global almost 80 million barrels per day of oil [86]. Based on the global estimation, the water to oil ratio is approximately 3:1. On the contrary, for NG production in the Qatari north field, the ratio of water to gas is approximately 1.20 based on Qatar Petroleum research [87]. Furthermore, Qatar has made a significant investment in liquefied natural gas (LNG), and it produces 77 million tons per year. Moreover, the leading petroleum company in Qatar has added a fourth LNG production line, and is planning to increase its production capacity from the north field to reach 110 million tons a year. Currently, 
liquefied natural gas companies in Qatar operate 14 LNG trains with a total annual production capacity of 78 million tons [88]. However, several regulations in Qatar are set by the Ministry of the Municipality and Environment to control and regulate the production of produced water. To comply with the regulations of the Ministry of the Environment and ensure sustainable long-term disposal, the liquefied natural gas company in Qatar created 14 trains between 1999 and 2011, producing 78 million tons per year of LNG, and in 2015 they exported 78.4 million tons. Additionally, liquefied natural gas companies in Qatar constructed two advanced wastewater recycling and reduction (WRR) plants for numerous LNG trains at Ras Laffan, Qatar. However, the reverse osmosis (RO) process is the main advanced technology, since it will produce permeate for feeding the boilers, whereas all other supplementary treatments serve as pretreatment stages to eliminate other pollutants, for instance, hydrogen sulfide $\left(\mathrm{H}_{2} \mathrm{~S}\right)$, dispersed \& emulsified oil, organics, and suspended solids. The produced water will be combined with the RO brine and injected into disposal wells, causing a reduction of total water disposal volume. On the other hand, in 2018, the major petroleum company in Qatar was awarded a FEED contract for three new LNG trains and added a fourth LNG mega train to reach a capacity of 110 million tons per annum (MTPA), which will be used to service expansion of the North field development.

\section{Onshore and Offshore Produced Water Production}

Qatar has the world's third-largest reserve of natural gas after Russia and Iran. Moreover, Qatar is the second-largest exporter of natural gas, owning $14 \%$ of the total global gas reserves. Moreover, Qatar's Supreme Council for the Environment and Natural Reserves (SCENR) has assigned all oil production facilities to treat the PW in the state, in order to achieve the recent maximum oil/water concentration limit of $40 \mathrm{ppm}$, while maintaining an average of $20 \mathrm{ppm}$ [89]. In Qatar, seven main offshore production stations (PS) operate on eight oil production fields. The first PS1 is located in the northeast of Qatar, within a $45 \mathrm{~km}$ distance from Al-Rayyan city, and it operates on two fields that were first discovered as oil wells in 1960, Idd- El Shargi north dome and Idd- El Shargi south dome. The second and third PS are operated by Qatar Petroleum, and have two fields in the northeast in Maydan Mahzam (MM) and Bul Hanine (BH) fields of Qatar. These two fields are popular in producing high-quality crudes and associated gas, which began production in 1965 and 1972, respectively. Moreover, Idd-El Shargi and Al-Rayyan fields are operated by Occidental Petroleum of Qatar Ltd., Al-Shaheen field by Maersk Oil Qatar, Al-Khalij field by TOTAL Exploration \& Production Qatar [86], and finally, AlKarkara field by QP Development Company. Another field is El-Bunduq field, which is operated in cooperation with United Arab Emirates and is operated by Bunduq Company Ltd. (Abudhabi, United Arab Emirates) [81]. Nevertheless, Dukhan oil field has onshore field operated by Qatar Petroleum, which is a long narrow anticline over the north-south for around $70 \mathrm{~km}$. The production in the Dukhan field started in 1940 after its discovery in 1939 [90]. Dukhan covers four reservoirs: Fahahil, Khatiyah, Jaleha, and Diyab, one of which contains non-associated gas, and the other three are oil reservoirs. The oil and gas fields are divided into four degassing stations: Khatiyah (north, main, and south), Fahahil Main, and Jaleha. Dukhan field produces up to 335,000 barrels per day [81]. Total is the operator, as well as a shareholder of AlKhalij offshore oilfield, sited on Block 6 in Halul, which was established in1991. Production from this geographically complicated oilfield began in 1997, and currently, approximately 22,000 barrels of oil/day are taken through two subsea pipelines to a treatment plant on Halul Island. In 2015, a breakthrough 200 million barrels of oil was produced from this field. In 2016, Total gained a bid for Qatar's Al-Shaheen offshore oilfield, with a production capacity of 300,000 barrels/day. North Oil Company (NOC), which was founded as a partnership between Qatar Petroleum $(70 \%)$ and Total $(30 \%)$, began the operation of the massive oil field starting in 2017. This field generates 300 thousand barrels of oil/day. Table 4 presents the PQ characteristics obtained from a Qatar-based natural gas field [91]. 
Table 4. PQ characteristics obtained from a Qatar-based natural gas field [91].

\begin{tabular}{ccc}
\hline Different Parameters & \multicolumn{2}{c}{ PW Characteristics } \\
\hline & Filtered Water & Raw PW \\
\hline Xylene $(\mathrm{mg} / \mathrm{L})$ & 3.11 & 3.43 \\
\hline Ethyl benzene $(\mathrm{mg} / \mathrm{L})$ & 1.05 & 1.22 \\
\hline Toluene $(\mathrm{mg} / \mathrm{L})$ & 3.21 & 3.8 \\
\hline Benzene $(\mathrm{mg} / \mathrm{L})$ & 16.1 & 21 \\
\hline Total phosphorus $(\mu \mathrm{g} / \mathrm{L})$ & 180 & 357.78 \\
\hline Total Nitrogen $(\mathrm{mg} / \mathrm{L})$ & 27.6 & 389.1 \\
\hline Total organic carbon $(\mathrm{mg} / \mathrm{L})$ & 317 &
\end{tabular}

\section{Factors Affecting Production Volume of Produced Water}

The production volume of produced water is affected by several factors. Drilling type is considered as an important factor, for example, the horizontal well produces PW at a higher rate, as compared to the vertical well at the same drawdown. Furthermore, the next important factor is the position of the well, i.e., whether it is placed within heterogeneous or homogeneous reservoirs. An inappropriately drilled well or one that has been inappropriately positioned inside the reservoir structure can lead to an earlier than expected water production. Moreover, the vertical and horizontal well is affected by the type of the reservoirs, for instance, when the homogeneous reservoirs are using the horizontal wells, the production of water is reduced, and the volume of water injected in the oil recovery is enhanced. Further, a perforated completion proposes a higher degree of control in the hydrocarbon-production zone. Special intervals can either aim for improved hydrocarbon production, or be prevented or plugged for minimizing the water production. It is important to mention that inadequate mechanical integrity of drilling could enhance PW production [81,92]. Moreover, the type of water separation as well as treatment facilities influence the production volume of the produced water. Generally, the surface separation, as well as treatment facilities, are employed for the management of produced water. Nevertheless, this type of operation requires lifting costs for bringing the water to the surface, as well as equipment and chemical expenses for water treatment. Substitutes for surface treatment can be downhole separation apparatus that permit the produced water for remaining downhole, thus preventing certain lifting, surface capability, and corrosion expenses, as well as related challenges. Furthermore, the inadequate volume of produced water intended for water flooding impacts the produced water's production volume. If inadequate produced water is obtainable for water flooding, extra source waters should be acquired for augmenting the injection of produced water. In order to maintain a successful water flood operation, the water employed to inject should be of high quality that does not harm the reservoir rock. Previously, freshwater was frequently employed in water floods. Subsurface communication difficulties are another significant factor influencing the production volume of the produced water. Near-well bore communication issues such as barrier breakdowns, channels behind casing, and completions near or into water could lead to more volumes of produced water. Additionally, reservoir communication challenges such as cresting, coning, fracturing out of the hydrocarbon producing zone, and channeling through high permeability zones or fractures could also promote higher volumes of produced water. All of the above-stated factors could increasingly influence the produced water's volume that is finally managed in the course of the life cycle of a well, as well as a project. With augmented volumes of produced water, the financial feasibility of a project becomes an issue, due to the disposal expenses of water, the enlarged size and expense of water treating facilities, as well as related treatment chemicals, the extra cost of lifting water versus hydrocarbons, and loss of recoverable hydrocarbons. 


\section{Produced Water Characterization}

The chemical and physical properties of PW differ in accordance with geographic location, depth, the geologic formation of the production well, geochemistry of the component with the hydrocarbon, and the reservoir lifetime [81,93-95]. Moreover, the chemical properties vary based on the different chemicals added within the production process and the composition of oil and gas in the reservoir. It consists of organic and inorganic materials, metals, and impurities such as radioisotopes [5,96,97], in addition to inorganic anions (chlorides, sulfates, and phosphates), sulfide, metals, cations, total suspended solids (TSS), heavy metals, chemical oxygen demand (COD), biochemical oxygen demand (BOD), total organic carbon (TOC), dissolved and dispersed oil compounds, dissolved gases, and conductivity. Table 5 illustrates the characteristic of oilfield PW content [81].

Table 5. Typical composition of produced water from Qatar. Reproduced from reference [98].

\begin{tabular}{cc}
\hline Parameter & Concentration $(\mathbf{m g} / \mathbf{L})$ \\
\hline Total dissolved solid & $1000-400,000$ \\
\hline Total suspended solid & $98-116$ \\
\hline Potassium & $10-12$ \\
\hline Sodium & $5462-5836$ \\
\hline Chlorine & $8475-9219$ \\
\hline Total organic carbon & $45-71$ \\
\hline Magnesium & $114-118$ \\
\hline Calcium & $356-372$ \\
\hline Sulfate radical & $61-68$ \\
\hline Total nitrogen & $23-26$ \\
\hline
\end{tabular}

In this section, the characteristics of produced water generated in Qatar are initially defined, and then discussed in detail.

\section{1. $\mathrm{pH}$}

$\mathrm{pH}$ is used to find the acidity and alkalinity of the solution. In 1992, Jacobs et al. [99] presented the acidic nature of the PW solution obtained from gas fields. The team stated that the level of $\mathrm{pH}$ in $\mathrm{PW}$ obtained from gas operations grounds (ranging from 3.5 to 5.5) is more acidic than PW from oil fields (ranging from 6 to 7.7).

\subsection{Chemical Oxygen Demand (COD)}

COD is a basic method to discover the quantities of contaminants that cannot be oxidized naturally in the produced water. It is measured as the milligrams of $\mathrm{O}_{2}$ per liter of the sample that is consumed by the chemical demand. Being conscious of the COD amount in the sample leads to the determination of the amount of suspended contaminants, as well as dissolved contaminants present in water [76].

\subsection{Total Organic Carbon (TOC)}

TOC is used for determining the total amount of organic compounds in PW in $\mathrm{mg} / \mathrm{L}$. It is also important to measure the level of pollution in the wastewater. TOC accurately measures the concentration of carbon found in an organic compound, and is usually implemented as a non-precise indicator of water quality. Practically, all TOC analyzers determine the $\mathrm{CO}_{2}$ formed when organic carbon is oxidized and when inorganic carbon is acidified. The concentration of TOC in PW differs significantly from one well to another [76].

\subsection{Biochemical Oxygen Demand (BOD)}

$\mathrm{BOD}$ is a bioassay process used to determine the concentration of oxygen consumed in the disintegration procedure of organic matter by bacteria. The process includes the 
measurements of dissolved oxygen mass for a specific volume of solution required for the biochemical oxidation procedure. There are specific conditions to perform this process, such as a temperature $20^{\circ} \mathrm{C}$, full darkness, and monitoring should be carried out over a period of five days. It is measured in $\mathrm{mg} / \mathrm{L}$. It has been found that PW from the gas field has higher concentrations of BOD than from the oilfield. The high amount of BOD in PW leads to reduced water quality. Therefore, the PW must be significantly oxidized to avoid the ejection of higher BOD materials into the receiving streams [76].

\subsection{Conductivity and Salinity}

Conductivity is the measure of the capability of water to pass the electrical flow. Conductivity is precisely related to the concentration of ions present in the water. In one research study, it was noted that the conductivity of PW from natural gas fields was in the range of $4200-180,000 \mu \mathrm{S} / \mathrm{cm}$ [100]. The conductivity is dependent on the value of the temperature, $\mathrm{pH}$, and on the amount of carbon dioxide dissolved in the $\mathrm{PW}$ to develop ions. There are two types of conductivity: intrinsic conductivity due to the mentioned factors or extraneous conductivity due to ion's concentration already existing in the sample such as chloride, calcium, sodium, magnesium, and other ions [81]. On the other hand, salinity is the measurement of salts present in the solution determined by the electrical conductivity (EC) of a liquid. The salinity concentration could range from a very small amount of salt to an extreme content that can be higher than that of seawater [76].

\subsection{Ions and Inorganic Constituents}

Produced water contains various dissolved ions and inorganic elements. Ions are charged particles, such as sodium chloride $(\mathrm{NaCl})$ salt dissolved, and formed $\mathrm{Na}^{+}$and $\mathrm{Cl}^{-}$. To measure the hazardous nature of soil and water, the sodium adsorption ratio (SAR) scale is used [101]. It determines the suitability of water for irrigation, and represents the relationship of the sodium with magnesium and calcium concentration. Overall, higher concentrations of magnesium, calcium, and sodium, and the lesser SAR value are considered as better water for irrigation. In PW, the main inorganic constituents are sodium, calcium, magnesium, bicarbonate, aluminum, arsenic, barium, chloride, sulfate, and potassium. There are minor ions present in inorganic constituents, such as metals consisting in a different range of concentrations alongisde the non-metals, likely boron and fluoride. However, the major ions are found in moderately higher concentrations than minor ions.

\subsection{Total Suspended Solids (TSS)}

Suspended solids or TSS are found in a smaller size from reservoir rocks such as quartz and clays. Moreover, PW contains various types of solids or dissolved impurities that cannot pass through the filter. The type of TSS differs depending on the size such as in hydraulic fracture, the proppant size ranges from $1.0 \mathrm{~mm}$ to larger, whereas iron sulfide particles range from $0.1 \mu \mathrm{m}$ to smaller than this. Predominately, TSS is denser as compared to the PW or oil, thus it typically sinks to the base of the vessels, tanks, or pipes driving many operating challenges [76,81].

\subsection{Heavy Metal}

The concentration of heavy metals depends on the formation of geology and the age of the wells. PW tend to contain lead $(\mathrm{Pb})$, iron $(\mathrm{Fe})$, zinc $(\mathrm{Zn})$, barium $(\mathrm{Ba})$, selenium $(\mathrm{Se})$, strontium $(\mathrm{Sr})$, and manganese $(\mathrm{Mn})$ in wide concentrations. In addition, chromium $(\mathrm{Cr})$, vanadium $(\mathrm{V})$, copper $(\mathrm{Cu})$, cadmium $(\mathrm{Cd})$, mercury $(\mathrm{Hg})$, and nickel $(\mathrm{Ni})$ are some popular heavy metal pollutants present in trace amounts in the PW. The concentration of the metals depends on the surroundings, where high concentrations cause toxicity and bioaccumulation [81]. 


\subsection{Total Kjeldahl Nitrogen (TKN)}

Total Kjeldahl Nitrogen is the total concentration of organic nitrogen and ammonia. TKN is a method to determine the total nitrogen in an organic substance, involving inorganic compounds such as ammonia and ammonium $\left(\mathrm{NH}_{3} / \mathrm{NH}_{4}{ }^{+}\right)$in water. This method was established in 1883 by Johan Kjeldahl. The nitrogen constituents and their relationship are shown in Figure 2 [81].

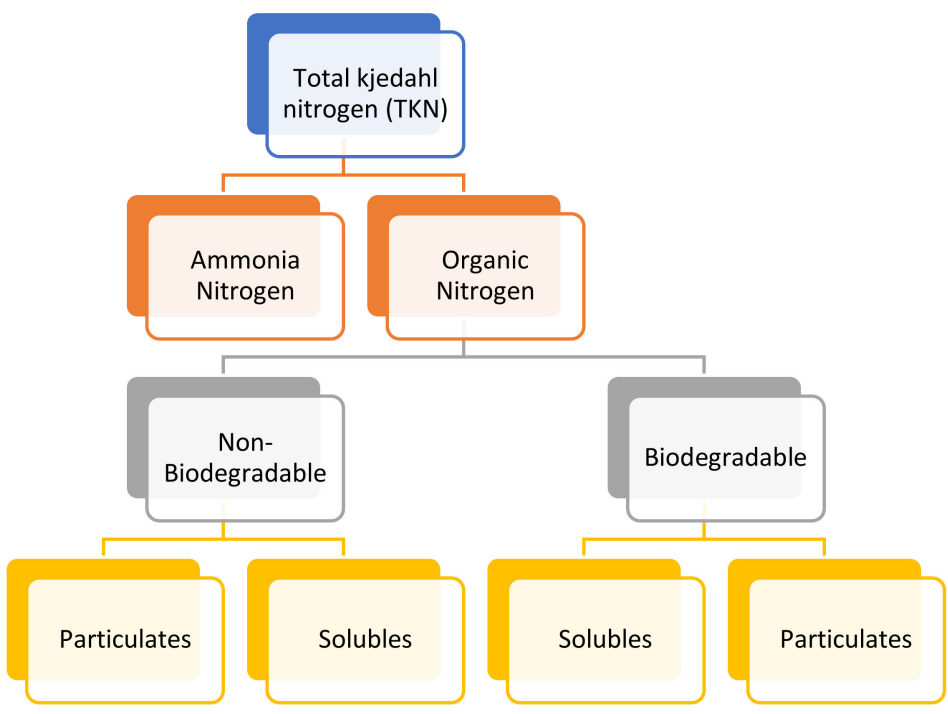

Figure 2. Total Kjedahl nitrogen (TKN) fractions.

\subsection{Total Petroleum Hydrocarbon (TPH)}

Total petroleum hydrocarbons represents the number of hydrocarbons in the sample, mainly consisting of carbon and hydrogen. It is present either in suspended petroleum hydrocarbon or dissolved form. Petroleum hydrocarbon is a combination of hydrocarbon containing mostly four groups: BTEX (volatile aromatic compounds: benzene, toluene, ethylbenzene, and xylene), phenols, polycyclic aromatic hydrocarbons (PAHs), and NPD (naphthalene, phenanthrene, and dibenzothiophene). Generally, hydrocarbons are categorized into three major categories, namely aromatics, unsaturated, and saturated.

BTEX compounds are naturally created in oil and gas, such as gasoline, diesel fuel, and natural gas. BTEX are very volatile, and therefore they are lost rapidly through PW treatment, such as in the early mixing in the sea or by air stripping [102]. Benzene considers as the most abundant compound among all BTEX components, but when the alkylation is increased, its amount decreases. [76].

\subsection{Total Nitrogen (TN)}

Total nitrogen is the collective quantity of the entire nitrogen compounds (ammonia, nitrates, and nitrites) in the PW. It contains organically bonded nitrogen, nitrate-nitrogen $\left(\mathrm{NO}_{3}-\mathrm{N}\right)$, ammonia-nitrogen $\left(\mathrm{NH}_{3}-\mathrm{N}\right)$, and nitrite-nitrogen $\left(\mathrm{NO}_{2}-\mathrm{N}\right)$. It can be found by monitoring for free-ammonia, nitrate-nitrite, and organic nitrogen compounds individually, and then summing the values of the components together.

In Qatar, Hussain, A., Minier-Matar, J. et al. [49] performed PW treatment, and the PW was obtained from an offshore Qatari gas processing operation. In the study, the PW for the biotreatability test was characterized. Nitrogen and phosphorus were added to guarantee sufficient nutrients [49]. Additionally, the characterization of the process water for the same test is summarized with PW data in Table 6. 
Table 6. Characterization of PW and process water from oil-producing companies in Qatar.

\begin{tabular}{|c|c|c|c|c|c|c|}
\hline Title & Authors/Date/Reference & Parameters & Unit & Value & Parameters & Value \\
\hline \multirow{19}{*}{$\begin{array}{l}\text { Advanced Technologies } \\
\text { for Produced } \\
\text { water treatment }\end{array}$} & \multirow{19}{*}{$\begin{array}{c}\text { Hussain, A., } \\
\text { Minier-Matar, J., et al./ } \\
2014 \text { [49] }\end{array}$} & \multicolumn{3}{|c|}{ Produced Water Source and Composition } & \multicolumn{2}{|c|}{$\begin{array}{l}\text { Process Water Source } \\
\text { and Composition }\end{array}$} \\
\hline & & COD & $\mathrm{mg} / \mathrm{L}$ & 1572 & COD & $397 \mathrm{mg} / \mathrm{L}$ \\
\hline & & TOC & $\mathrm{mg} / \mathrm{L}$ & 491 & TOC & $114 \mathrm{mg} / \mathrm{L}$ \\
\hline & & $\mathrm{TN}$ & $\mathrm{mg} / \mathrm{L}$ & 43 & $\mathrm{TN}$ & $31 \mathrm{mg} / \mathrm{L}$ \\
\hline & & Oil \& grease & $\mathrm{mg} / \mathrm{L}$ & 47 & Oil \& grease & $10 \mathrm{mg} / \mathrm{L}$ \\
\hline & & TPH & $\mathrm{mg} / \mathrm{L}$ & 45 & $\mathrm{TPH}$ & $9 \mathrm{mg} / \mathrm{L}$ \\
\hline & & Chloride & $\mathrm{mg} / \mathrm{L}$ & 2265 & Chloride & $17 \mathrm{mg} / \mathrm{L}$ \\
\hline & & Sodium & $\mathrm{mg} / \mathrm{L}$ & 1030 & Sodium & $359 \mathrm{mg} / \mathrm{L}$ \\
\hline & & Calcium & $\mathrm{mg} / \mathrm{L}$ & 329 & Calcium & $3 \mathrm{mg} / \mathrm{L}$ \\
\hline & & Sulfide & $\mathrm{mg} / \mathrm{L}$ & 307 & Sulfide & $307 \mathrm{mg} / \mathrm{L}$ \\
\hline & & Magnesium & $\mathrm{mg} / \mathrm{L}$ & 61 & Magnesium & $0.2 \mathrm{mg} / \mathrm{L}$ \\
\hline & & Bromide & $\mathrm{mg} / \mathrm{L}$ & 51 & Bromide & $<0.5 \mathrm{mg} / \mathrm{L}$ \\
\hline & & Sulfate & $\mathrm{mg} / \mathrm{L}$ & 54 & Sulfate & $9 \mathrm{mg} / \mathrm{L}$ \\
\hline & & Potassium & $\mathrm{mg} / \mathrm{L}$ & 44 & Potassium & $1.5 \mathrm{mg} / \mathrm{L}$ \\
\hline & & Thiosulfate & $\mathrm{mg} / \mathrm{L}$ & 14 & Thiosulfate & $43 \mathrm{mg} / \mathrm{L}$ \\
\hline & & Acetate & $\mathrm{mg} / \mathrm{L}$ & 347 & Acetate & $3.2 \mathrm{mg} / \mathrm{L}$ \\
\hline & & Ammonium & $\mathrm{mg} / \mathrm{L}$ & 11 & Ammonium & $11 \mathrm{mg} / \mathrm{L}$ \\
\hline & & Conductivity & $\mu \mathrm{S} / \mathrm{cm}$ & 7200 & Conductivity & $1761 \mu \mathrm{S} / \mathrm{cm}$ \\
\hline & & TDS & $\mathrm{mg} / \mathrm{L}$ & 5189 & TDS & $1491 \mathrm{mg} / \mathrm{L}$ \\
\hline & & \multicolumn{5}{|c|}{ Produced and process water (PPW) } \\
\hline \multirow{14}{*}{$\begin{array}{l}\text { Application of forward } \\
\text { osmosis for reducing } \\
\text { volume of } \\
\text { produced/Process } \\
\text { water from oil and gas } \\
\text { operations } \\
\text { Gas field } \\
\text { produced/process } \\
\text { water treatment using } \\
\text { forward osmosis } \\
\text { hollow fiber membrane: } \\
\text { Membrane fouling and } \\
\text { chemical cleaning }\end{array}$} & \multirow{14}{*}{$\begin{array}{l}\text { Minier-Matar, J., et al./ } \\
2015 \text { [50] } \\
\text { Zhao, S., Minier-Matar, J., } \\
\text { and et al./2017 [103] }\end{array}$} & TOC & $\mathrm{mg} / \mathrm{L}$ & 33 & & \\
\hline & & Chloride & $\mathrm{mg} / \mathrm{L}$ & 286 & & \\
\hline & & Sodium & $\mathrm{mg} / \mathrm{L}$ & 329 & & \\
\hline & & Calcium & $\mathrm{mg} / \mathrm{L}$ & 38 & & \\
\hline & & Sulfate & $\mathrm{mg} / \mathrm{L}$ & 349 & & \\
\hline & & Magnesium & $\mathrm{mg} / \mathrm{L}$ & 8.7 & & \\
\hline & & Bromide & $\mathrm{mg} / \mathrm{L}$ & 5.6 & & \\
\hline & & Potassium & $\mathrm{mg} / \mathrm{L}$ & 4.7 & & \\
\hline & & Ammonium & $\mathrm{mg} / \mathrm{L}$ & 8.5 & & \\
\hline & & Alkalinity & $\mathrm{mg} / \mathrm{L}$ & 223 & & \\
\hline & & $\mathrm{PH}$ & & 8 & & \\
\hline & & Conductivity & $\mu \mathrm{S} / \mathrm{cm}$ & 1810 & & \\
\hline & & TDS & $\mathrm{mg} / \mathrm{L}$ & 1526 & & \\
\hline & & Turbidity & NTU & 32 & & \\
\hline & & \multicolumn{5}{|c|}{ Produced and process water (PPW) } \\
\hline \multirow{9}{*}{$\begin{array}{l}\text { Application of Hollow } \\
\text { Fiber Forward Osmosis } \\
\text { Membranes for } \\
\text { Produced and Process } \\
\text { Water Volume } \\
\text { Reduction: An Osmotic } \\
\text { Concentration Process }\end{array}$} & \multirow{9}{*}{$\begin{array}{l}\text { Minier-Matar, J., } \\
\text { Santos, A., et al./ } 2016 \text { [51] }\end{array}$} & TOC & $\mathrm{mg} / \mathrm{L}$ & 120 & & \\
\hline & & Chloride & $\mathrm{mg} / \mathrm{L}$ & 284 & & \\
\hline & & Sodium & $\mathrm{mg} / \mathrm{L}$ & 345 & & \\
\hline & & Calcium & $\mathrm{mg} / \mathrm{L}$ & 38 & & \\
\hline & & Sulfate & $\mathrm{mg} / \mathrm{L}$ & 347 & & \\
\hline & & Magnesium & $\mathrm{mg} / \mathrm{L}$ & 8 & & \\
\hline & & Bromide & $\mathrm{mg} / \mathrm{L}$ & 5 & & \\
\hline & & Potassium & $\mathrm{mg} / \mathrm{L}$ & 4.5 & & \\
\hline & & Phosphate & $\mathrm{mg} / \mathrm{L}$ & $<0.1$ & & \\
\hline
\end{tabular}


Table 6. Cont.

\begin{tabular}{|c|c|c|c|c|c|c|}
\hline Title & Authors/Date/Reference & Parameters & Unit & Value & Parameters & Value \\
\hline & & Total nitrogen & $\mathrm{mg} / \mathrm{L}$ & 28 & & \\
\hline & & Inorganic carbon & $\mathrm{mg} / \mathrm{L}$ & 31 & & \\
\hline & & $\mathrm{PH}$ & & 8 & & \\
\hline & & Conductivity & $\mu \mathrm{S} / \mathrm{cm}$ & 1725 & & \\
\hline & & TDS & $\mathrm{mg} / \mathrm{L}$ & 1550 & & \\
\hline & & $\begin{array}{c}\text { Osmotic pressure } \\
\left(25^{\circ}\right)\end{array}$ & bar & 1 & & \\
\hline & & & & duced & & \\
\hline \multirow{19}{*}{$\begin{array}{l}\text { Assessing the } \\
\text { Biotreatability of } \\
\text { Produced Water from } \\
\text { a Qatari Gas Field }\end{array}$} & \multirow{19}{*}{ Janson, A., et al./2015 [52] } & COD & $\mathrm{mg} / 1$ & 1572 & & \\
\hline & & TOC & $\mathrm{mg} / \mathrm{L}$ & 491 & & \\
\hline & & $\mathrm{TN}$ & $\mathrm{mg} / \mathrm{L}$ & 34 & & \\
\hline & & Oil \& grease & $\mathrm{mg} / \mathrm{L}$ & 47 & & \\
\hline & & TPH & $\mathrm{mg} / \mathrm{L}$ & 45 & & \\
\hline & & Chloride & $\mathrm{mg} / \mathrm{L}$ & 2265 & & \\
\hline & & Sodium & $\mathrm{mg} / \mathrm{L}$ & 1030 & & \\
\hline & & Calcium & $\mathrm{mg} / \mathrm{L}$ & 329 & & \\
\hline & & Sulfide & $\mathrm{mg} / \mathrm{L}$ & 828 & & \\
\hline & & Magnesium & $\mathrm{mg} / \mathrm{L}$ & 61 & & \\
\hline & & Bromide & $\mathrm{mg} / \mathrm{L}$ & 51 & & \\
\hline & & Sulfate & $\mathrm{mg} / \mathrm{L}$ & 54 & & \\
\hline & & Potassium & $\mathrm{mg} / \mathrm{L}$ & 44 & & \\
\hline & & Thiosulfate & $\mathrm{mg} / \mathrm{L}$ & 14 & & \\
\hline & & Acetate & $\mathrm{mg} / \mathrm{L}$ & 347 & & \\
\hline & & Ammonium & $\mathrm{mg} / \mathrm{L}$ & 11 & & \\
\hline & & Conductivity & $\mu \mathrm{S} / \mathrm{cm}$ & 7200 & & \\
\hline & & $\begin{array}{l}\text { Total Dissolved } \\
\text { solids }\end{array}$ & $\mathrm{mg} / \mathrm{L}$ & 5189 & & \\
\hline & & $\mathrm{PH}$ & & 4.3 & & \\
\hline
\end{tabular}

Another paper published by Minier-Matar, J. and co-authors (2015) [50] studied the reduction of the volume of produced/processed water (PPW) by $50 \%$ through using an application of forward osmosis. The PPW samples were received from oil and gas operations. To characterize the sample, ion chromatography was used to measure the anions and cations such as sulfate, sodium, chloride, and bromide. A conductivity detector was used to find the isolated analyte, while the metals, such as boron and strontium, were measured by inductively coupled plasma. A TOC analyzer, NDIR detector, and $\mathrm{pH} /$ conductivity meter were used to find Total organic carbon, Total carbon (TC), $\mathrm{CO}_{2}$, inorganic carbon, conductivity, and $\mathrm{pH}$ [9]. In the same year, Janson et al. [52] assessed the bio-treatability of PW extracted from a gas field operation (North field) in Qatar. Researchers characterized $1200 \mathrm{~L}$ of PW to ensure the stability of the composition. Moreover, the characterization data of the PW and PPW is presented in Table 6 [52]. Nonetheless, Zhao, S., Minier-Matar, J., et al. (2017) [103] characterized PPW from the same source as that reported by Minier-Matar, J. et al. [50]. The PPW was a combination of gas field produced water extracted from the offshore gas well and process water from onshore operations, with a blending ratio of 1:5 in Qatar. The studies demonstrated the application of hollow fiber FO membranes for produced and process water volume decline [50,103].

Redoua, A. and AbdulHamid, S. (2016) [66] presented an industrial application to remove kinetic hydrate inhibitor (KHI) polymers from re-injected $\mathrm{PW}$ streams. The existence of KHI polymers in the injected PW led to long-term damage in the reservoir. The PW in 
this project contained KHI treated at the onshore gas processing facilities in Ras Laffan industrial city. A recent paper published by Benamora, A. et al. [79] studied the effect of fluid speed and temperature on the corrosion performance of carbon steel pipelines in Qatari oilfield-produced water. In order to understand the chemical composition of the $\mathrm{PW}$, the sample was supplied from a gas oilfield north of Qatar and the water treatment plant in Qatar.

In 2014, Ahan, J. et al. [81] characterized PW samples supplied from an offshore oil field in Qatar. Chemical and physical characterizations were carried out, in addition to the analysis of factors such as $\mathrm{pH}$, conductivity, concentration of heavy metals, and total Kjeldahl nitrogen [81]. The samples were provided from either oil or gas fields in Qatar, including natural gas from the north field and TOTAL company in Halul Island station. The PW samples were analyzed for different metals and chemical constituents. It was characterized based on total and readily biodegradable COD, BOD, $\mathrm{pH}$, alkalinity, salinity, conductivity, the total quantity of hydrocarbons present in the sample, total solids (TS), BTEX concentration, totals dissolved solids (TDS), phosphate, heavy metals, ammonia nitrogen and phenol, the concentration of ions, total sulfide, dissolved $\mathrm{CO}_{2}$, and oil droplet size distribution. Abdul-Hakim et al. (2016) [72] studied an application of microalgae using $\mathrm{PW}$ from different sources of the petroleum industry in Qatar. In the same year, Al-Kaabi et al. [76] characterized PW samples supplied from an LNG plant at the north field in Qatar, and enhanced the quality of the samples using different treatments discussed in the next section. Shaikh et al. [74] and Atia, A. et al. [75] characterized PW samples provided by a Qatar-based company and studied its effect on the plants for irrigation. Although two studies conducted by Aly et al. [68] and Al-Ghoul et al. [69] used synthetic PW samples for electrocoagulation process. TOC, TPH, O and G, SS, and turbidity were obtained for the PW samples.

\section{Treatment Processes}

The main target of treating the produced water is to eliminate all the toxic constituents present in it. In 2005, Arthur and co-authors [75] studied the different produced water treatment techniques to remove the soluble organics, gases, impurities, oil and grease, dissolved solids and salts, hardness, salinity, and to remove NORM and disinfectants. Currently, various techniques can be used to manage and treat $\mathrm{PW}$ to promote water conservation and sustainability. The technologies designed for PW treatment are established based on whether the installation is onshore or offshore. In general, the installation for offshore is more significant than onshore, since the offshore wells function for longer to stabilize the capital investment. Figure 3 shows the different offshore produced water treatment stages. In onshore facilities, the produced water generated will be re-injected into disposal wells. Therefore, the design of treatment facilities is significant in order to remove most of the contamination. However, in offshore facilities, the treatment required is to only reduce the $\mathrm{O}$ and $\mathrm{G}$ to acceptable levels so it can be discharged into the sea [76]. In Qatar, the process of the PW begins with fluids extraction from the reservoirs. Once this happens, one or more techniques are used to treat and separate the oil droplet from the water. The separation technique is highly dependent on the production station, for instance, several stations use three-phase separators to separate oil from water in the offshore station, while others degasify the fluid and then deliver it to storage tanks in Halul through pipelines. Moreover, the separation of oil from water in the storage tank depends on the gravity and density difference. Then, the water must be treated as it may have dissolved and dispersed the droplets of oil. Later, the PW is either re-injected in the reservoirs or disposed of into disposal jackets in the water. More importantly, the type of treatment is chosen based on the oil quantity present in the PW, where it varies between 0.5 to $200 \mu \mathrm{m}$ in diameter [81]. It is worth mentioning that, in oil/gas industries, the pretreatment techniques are used as an initial step. The gravity separation used widely depends on the performance of the oil/water separator, the system surface overflow rate, and it increases the velocity of the individual oil droplets. Then, further treatment technologies are potentially performed such as micro 
and ultra-filtration, biological-based treatments that are generally used for "downstream" refining processes, forward and reverse osmosis ( $\mathrm{FO}$ and $\mathrm{RO}$ ), separation by hydrocyclones, polymer membranes, adsorption, wetlands, aerated lagoons, various flotation methods (column flotation, dissolved air, electro and induced air), membrane bioreactors, activated sludge treatment, coalescence, chemical coagulation, and electrocoagulation $[61,62,78]$. Due to economic and operational limitations such as high operational, low efficiency, and capital cost, sludge has not been widely implemented for PW treatment [61]. Moreover, to minimize the waste of water, a leading Qatar-based petrochemical company has established formal water to aid the producers to reduce the amount of PW, and reduce the expenses of treatment technologies besides looking for obtainable facilities to handle huge volumes of PW [76].

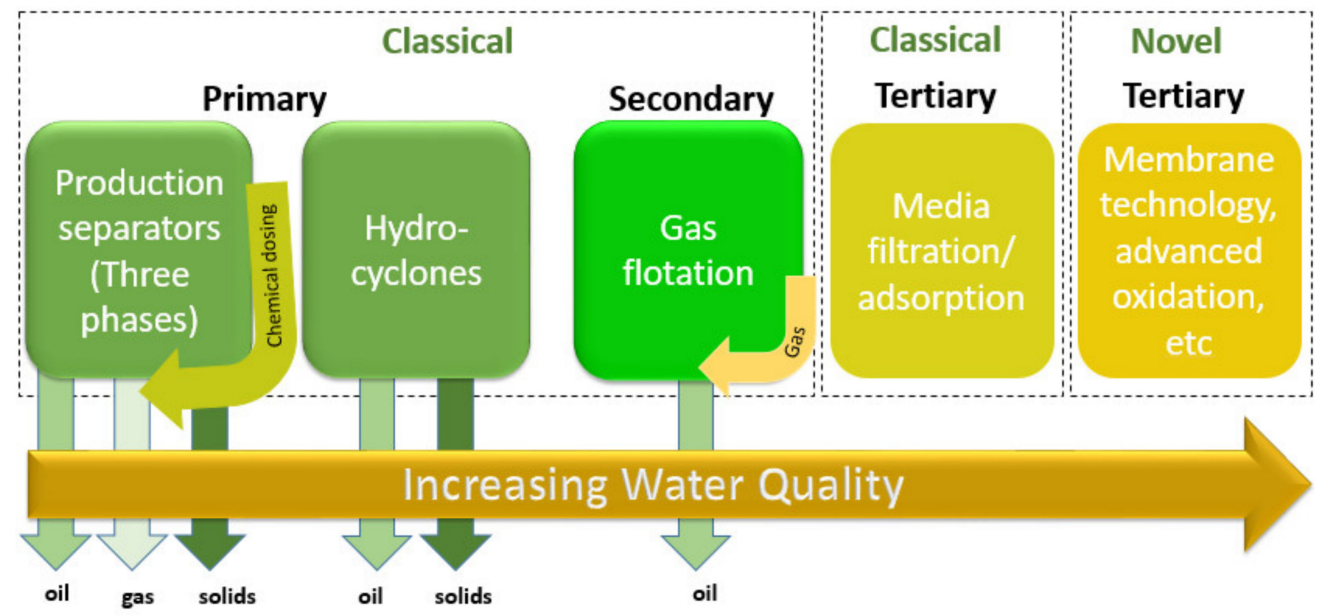

Figure 3. Offshore produced water treatment. Adapted from Reference [62].

Usually, in order to reach the environmental standards of treated water, two or more technologies are necessary to be combined to reach reasonable results. Techniques employing one technology will not be sufficient to treat PW and be acceptable, as per all global environmental standards [104]. Several stages with specified treatment processes are used to treat the pollutants in PW. Initially, physical treatment can be performed where the physical process is performed to remove solid and biomass without using chemicals or bacteria such as filtration. The second stage is a chemical treatment applied to remove the specific chemicals dissolved and suspended particles that are not able to be eliminated from PW through physical treatments. However, chemical treatments require additional costs for the chemicals used in flocculation and coagulation. The last stage is biological treatment using bacteria to remove the biodegradable material.

In this section, the treatment processes of PW conducted in Qatar are discussed in detail, including the final analysis of PW. Figure 4 illustrates the three types of treatments used for PW treatment.

\subsection{Gravity Separation and Adsorption}

The gravity separation tank is the most technique used to separate oil from water with various concentrations. It depends on the gravity forces to separate the oil from the PW by permitting the oil to float on the water surface, while the suspended solids and particulates are deposited at the bottom. Skimmer tanks, storage tanks, and vessels are examples of equipment used for the gravity separation technique. Centrifuges as well as hydrocyclones are equipment utilized for enhanced gravity separation [81]. The adsorption technique is useful to remove $80 \%$ of elements such as Fe, $\mathrm{Mg}$, BTEX, TOC, and heavy metals from PW. Different kinds of adsorbents such as organoclays, zeolites, activated carbon, and activated alumina could also be used [77]. Judd, S., et al. [62] examined the performance of offshore PW oil-separation by employing gravitation plus different technologies for reinjection. The data showed that, for the gravity separator technique, the corrugated plate interceptor 
(CPI), de-oiling hydrocyclones (HC), and induce gas flotation (IGF), there is an expected relationship between droplet size and the performance.
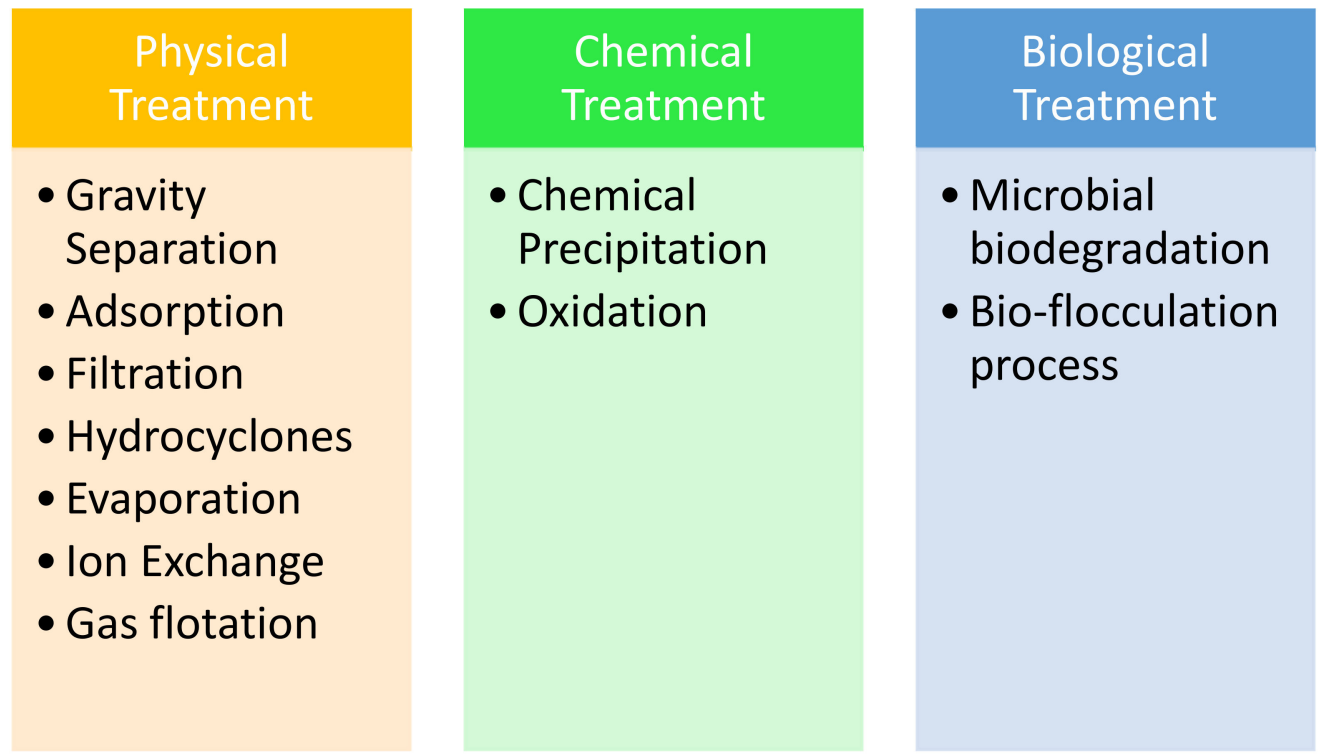

Figure 4. Physical, chemical, and biological treatments for PW.

\subsection{Hydrocyclones Separator}

Hydrocyclone units are a typical PW treatment device, usually placed downstream of gravity separators. They are considered as a mechanically closed vessel used to sort or separate particles in a liquid suspension based on the ratio of their centripetal force to fluid resistance. It works by directing inflow tangentially and closing the top of the cylindroconical vessel. This will spin the whole contents of the vessel, producing centrifugal force in the liquid [105]. Ahan, J. et al. [81] (2014) presented a comparison of two different stages of PW treatment in two different fields in Qatar. PW samples were obtained from two different fields: field A and field B. In field A, there are two stages of two-phase separation tanks joined with chemical injection and filtration unit, succeeded by gravitational separation tanks, while in field B, similar to field A, this starts with 2-stage separation with a chemical injection, but with three-phase separation tanks including the hydrocyclone, which is then followed by a surge drum. Therefore, the main difference between Fields A and B is the application of the treatment unit, where Field A depends on a gravity separation technology and Field B depends on the hydrocyclones as the main treatment unit for PW. The outcome after the characteristics of PW samples collected before and after the unit operations indicated that hydrocyclones are the more effective device in oil separation with $92.6 \%$ separation efficiency for $11 \mu$ oil droplet average size, with $312 \mathrm{~h}^{-1}$ as total capacity by volume. The study concluded that field A demanded enhancement in the filtration unit and more treatment units later, even when it minimized the hazardous pollutants better than in Field B [81].

\subsection{Filtration and Membrane}

Filtration technology is a useful technique to remove and eliminate suspended solids, dissolved salts, TOC, oil, and grease present in PW. The PW passes through layers of porous beads, gravel, anthracite, metal oxides, sand, walnut, ceramic, shells, and others. The efficiency of the filtration can reach more than $90 \%$ if it is improved by adding coagulants before the filtration process [75]. Sand, ultra, microfiltration, and nanofiltration (UF, MF, and NF) all are examples of the filtration process used to treat the PW. The leading crude oil producer company in Qatar aimed to limit the oil and TSS from PW using physical separation technologies to reach water quality standards, and then injected it in the disposal wells. Advanced water treatment technologies (AWTTs) such as membrane processes as UF, MF, 
NF, reverse and forward osmosis, membrane-bioreactors (MBRs), membrane distillation (MD), advanced oxidation process, and thermal evaporators were utilized to treat the PW. Hussain et al. [49] published their work using advanced technologies for PW treatment, which is implemented in an advanced water laboratory in Qatar. The PW was obtained from an offshore Qatari gas processing operation. The AWTTs were designated to target the main contaminants recognized in PW by using MBRs for organics, membrane distillation for salinity, and membrane process (organics and salinity) for treatment. Results showed a significant flux reduction when MBRs were used, and was then filtered over a reverse osmosis membrane. Moreover, it was found membrane distillation generated high-quality distillate water beside TOC and TDS rejections greater than $87 \%$ and $98 \%$, respectively. Overall, the treated PW using AWTTs proved that the process produced effluents that can be used in different applications such as livestock, irrigation, and industrial processes.

\subsubsection{Sand Filtration (SF)}

Sand filtration treatment is divided into different systems: slow sand filtration, high hydraulic loadings sand filtration (HLR), intermittent sand filtration (ISF), and sand/activated carbon filtration. In the slow sand filter, there is a layer of sand that allows for the pretreatment of water. Moreover, it controls the flow of water, the rate of water to be filtered in $\mathrm{m}^{3} / \mathrm{m}^{2} / \mathrm{h}$ ranging between 0.1 and 0.4 . The main element of slow sand filtration is the fine grains with a depth summation of almost $1.0 \mathrm{~m}$, and a diameter in the range of 0.15 and $0.35 \mathrm{~mm}$. During the filtration process, the suspended and colloidal materials are stuck at the higher part of the system. The disadvantage of the sand filter is that when the particles are clustered on top of each other, the system will get clogged, and hence the efficiency will be reduced [76]. HLR is produced by placing three identical sand columns parallelly. The column is filled at the bottom and the top with $10 \mathrm{~cm}$ of gravel, as well as $80 \mathrm{~cm}$ of fine sand. Several studies have proven the effect of the sand filter in reducing and removing the BOD, TSS, COD, TP, TN, and removing the oil \& grease. The intermittent sand filter is dependent on the concept of intermitted water levels, as well as its flow. Intermittent sand filtration purification is performed by chemical, physical, as well as biological mechanisms that could be employed to accomplish a remarkable decrease in COD and TSS [76].

The sand/activated carbon filtration system is capable to filter out pyrethroid pesticide residues, organochlorines, and organophosphates to their detection limit. The last type of sand filtration is clay, which is the main element present in the soil. The features of clay are high specific surface area, mechanical and chemical steadiness, high layered structure, and cation exchange capacity. These features offer it a significance in cation exchange capacity (CEC). Clay is capable of trapping metal particles from water when the water flows over soil into the ground, making it useful in eliminating the pollutants from water [76].

\subsubsection{Membrane Process (MP)}

MP is used to remove the kinetic hydrate inhibitor (KHI) from PW using an efficient membrane such as microfiltration, nanofiltration, ultrafiltration, and reverse osmosis membranes. The advantages of the treatment are either using a combination of numerous membrane processes such as NF or both RO and UF to aid in reducing KHI from the water, or involving other conventional water treatment methods such as clarification or media filtration. Recently, membrane separation has been recognized as a promising approach for handling a variety of oil/water mixtures owing to its low footprint and energy, high separation efficiency, time consumption, and simple operation [106,107]. However, as the inorganic membranes are hydrophilic in the air and convert to being oleophobic after immersion in water, the membranes with such an underwater superoleophobicity can prohibit the oil from touching the membrane surface [108]. Wang, K., et al. [108] reported a stretchable and winnable membrane of $\mathrm{ZnO}$ nanorods arrays with a three-dimensional structure conformally grown on woven carbon microfibers for effective oil/water treatment. Outcomes depicted the efficient separation of both oil/saline-water mixtures using the membrane and oil-in-water emulsions, merely driven with gravity, by high sepa- 
ration efficiency over 99\%, and extremely high permeation flux of $20,933.4 \mathrm{~L} \mathrm{~m}^{-2} \mathrm{~h}^{-1}$. Liu, Z. et al. [109] developed a fast and efficient separation membrane for the treatment of emulsified oil/water mixtures using ultra-long titanite nanofibers/cellulose microfibers. Adding to that, affordable materials and fabrication processes allowed for producing it as a favorable potential for industrial scale-up. Liu, Z. et al. [109,110] found good mechanical flexibility of the new membrane, as well as high separation efficiency up to $99.9 \%$ for oil/water emulsions with $3 \mu \mathrm{m}$ of oil droplet size. Additionally, it has a high water permeation flux at low operation pressure about $6.8 \times 10^{4} \mathrm{~L} \mathrm{~m}^{-2} \mathrm{~h}^{-1} \mathrm{bar}^{-1}$, which is assigned to the interconnected porous structure within the whole membrane, whereas the nanopores selective layer contributes to high oil separation.

\subsubsection{Membrane Distillation (MD)}

The mass transfer system can be controlled by partial vapor pressure alteration owing to a temperature difference. The difference in the temperature ranges between 10 to $20^{\circ} \mathrm{C}$ (warm and cold streams), and is adequate to obtain distilled water at the specific conditions. Membrane distillation is highly important for treating the salinity feed waters and reducing the salinity of PW [49]. Furthermore, MD in comparison with reverse osmosis is better in obtaining good, distilled water quality, which is not affected by high salinity. The $\mathrm{RO}$ system requires multiple passes, while MD uses a single pass to reach desired salt rejection, and uses low-grade waste heat, economic system. In the MD system, there are four main module configurations: air gap (AG), vacuum MD (VMD), direct contact MD (DCMD), and sweeping gas MD (SGMD) [56]. Minier-Matar, J. et al. [56] used flat sheet membranes with $0.014 \mathrm{~m}^{2}$, sandwiched between the feed and distillate plates to treat $\mathrm{PW}$. The results showed that the membrane was not affected by salt concentration, and the flux was stable. In addition, MD produced a high-quality distillate of brines from thermal desalination plants. For better efficiency, the MD process can be combined with some other membrane-based processes (Figure 5).

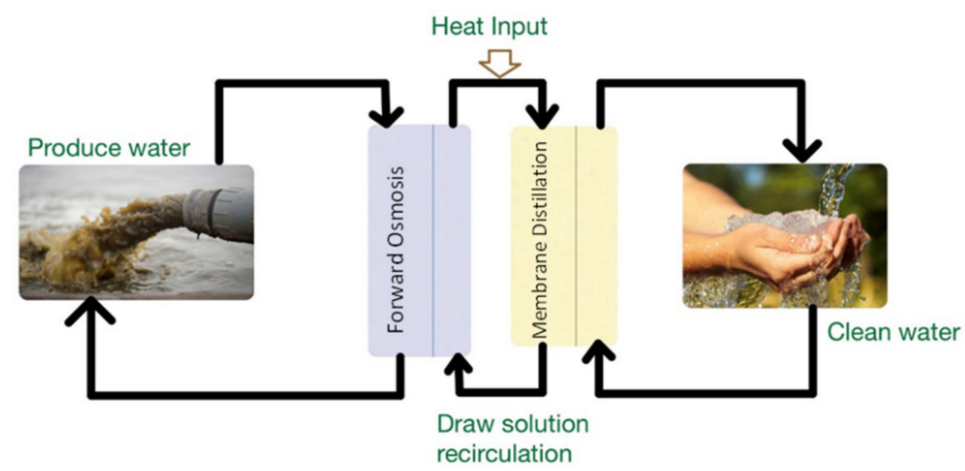

Figure 5. Schematics of the combination of membrane distillation and forward osmosis process.

\subsubsection{Membrane Bioreactors (MBRs)}

MBR is considered as an excellent method for treating different wastewater streams and industrial wastewaters. The advantage of MBRs is the membrane filter that is used to separate the sludge from the treated water. It is worth mentioning that MBRs have not yet been used to treat PW at upstream gas and oil operations. However, MBRs have offered better treatment for PW than conventional biological techniques, since the process uses an ultrafiltration and microfiltration membrane to isolate the sludge particle and emulsified oil and grease from the treated water [52]. In research done by Janson, A. et al. (2014) [52], the team assessed the biotreatability of PW obtained from the Qatari gas field. They performed a Box-Behnken test to optimize the bio-treatment of PW via a hollow fiber membrane over a range of hydraulic retention time (HRT) of 16 to around $30 \mathrm{~h}$, the temperature of 22 to $38{ }^{\circ} \mathrm{C}$ and solids-residence time (SRT) of 60 to 120 days. The outcomes displayed that, after $\mathrm{H}_{2} \mathrm{~S}$ stripping, and over eight months of testing, the chemical oxygen demand of a combination of PPW was approximatley $1300 \mathrm{mg} / \mathrm{L}$, appropriate for supporting the 
biological activity, with TDS of $5200 \mathrm{mg} / \mathrm{L}$ which was sufficiently low. Moreover, it was found that COD removal was between 54 to $63 \%$ by desorption, and no significant effect of the removal efficiency appeared in HRT, temperature, and SRT. Moreover, the pH value of MBRs' sludge ranged between 4.9-6, in contrast to the feed water with pH value of 4.3 , probably dueto low carbon removal. TOC results consistently followed the COD results with analogous removal values. However, all feedwater acetate and more than $90 \%$ of the oil/grease were separated by this technique. The authors concluded that MBRs treatment acted to be carbon limited, for the low volatile suspended solids concentration and accounting both for the absence of nitrification. Furthermore, in the same year by Janson, A. et al. [54], the team evaluated the biotreatability of PW during the summer season under varying conditions of solids retention time (SRT: 60-120 days), hydraulic retention time (HRT: $16-32 \mathrm{~h}$ ), and temperature $\left(22-38{ }^{\circ} \mathrm{C}\right)$. The authors found that TOC and COD existed in PW from Qatari gas field were removed by approximately $60 \%$ through MBR treatment. Moreover, it was discovered that there is no change of TOC \% and COD \% with any of the input parameters over the different ranges tested (SRT: $60-120 \mathrm{~d}$; HRT: 16-32 h; temperature: $22-38^{\circ} \mathrm{C}$ ).

\subsubsection{Ceramic Membrane}

The importance of ceramic microfiltration membranes for treating the PW from an Arabian Gulf oilfield has been conducted by applying a dedicated pilot plant. Moreover, the crossflow multi-channel ceramic membrane process has been studied for a pilot-scale to preserve the required treated water quality while changing the convenient membrane properties for sustaining the flux. In comparison with polymeric materials, the ceramic membrane exhibited the advantage of operation at high temperatures and increased fouling resistance. A significant number of studies for ceramic membrane application to PW have been conducted since the early 1990s [58,59]. Silicon carbide, SiC, titanium dioxide, $\mathrm{TiO}_{2}$ ceramic membranes with different pore sizes have been used in different studies. In a study by Zsirai, T., et al. (2016) [58], the team used crossflow multi-channel ceramic membrane technology to detect the suitable membrane properties for sustaining the flux through preserving the required treated water quality and minimizing the process footprint. Silicon carbide, $\mathrm{SiC}$, titanium dioxide, and $\mathrm{TiO}_{2}$ materials were utilized to produce membranes with different pore sizes. PW has been collected from oil platforms operating in the Arabian Gulf. Under the same operating and maintenance conditions of crossflow velocity, transmembrane pressure, and chemical and physical cleaning protocol, the results of $\mathrm{SiC}$ membranes were showed to be superior to $\mathrm{TiO}_{2}$ ones with respect to sustainable permeability. Moreover, after testing the membranes, the results demonstrated that $\mathrm{SiC}$ microfiltration membrane showed exceptionally high permeability and high treated water quality, but also the highest fouling propensity with $6.3-7.6 \mathrm{mg} / \mathrm{L} \mathrm{O \& G}$ and 4-8 NTU turbidity for MF (pore size $2 \mu \mathrm{m}$ ) and ultrafiltration (UF, pore size $0.04 \mu \mathrm{m}$ ) membranes. Furthermore, the outcomes indicated that the high fluxes ranging from 1300 to $1800 \mathrm{~L} \mathrm{~m}^{-2} \mathrm{~h}^{-1}$ are attainable for the technology, but this is conditional upon the application of an efficient chemical clean to sustain permeability and treated water over a long operational time. It was noted that on the chemically cleaned membrane there was a noticeable retrogradation in both permeate water quality and permeability with each consecutive experimental run. Consequently, the need to enhance the efficacy of the chemical clean-in-place (CIP) applied amidst runs to recover both the selectivity and permeability of the membrane. Hence, Zsirai, T., et al. (2018) [59] presented a CIP using a combination of citric acid and caustic soda $(\mathrm{NaOH})$. The results showed that the flux of $700 \mathrm{Lm}^{-2} \mathrm{~h}^{-1}$ was persistent through the application of $6 \mathrm{wt}$ \% citric acids with $6 \mathrm{wt} . \% \mathrm{NaOH}$ combined with backflushing at almost double the rate of the filtration cycle flux. Abdalla, M. et al. (2018) [60] published a study about the effect of combined oil/water emulsions and a colloidal particulate suspension (bentonite) on crossflow ceramic microfiltration (CFCMF) fouling and permeability recovery. They investigated the effect on both fouling through the filtration cycle and residual fouling of the $\mathrm{ZrO}_{2}-\mathrm{TiO}_{2}$ membrane. Outcomes showed that the permeability and 
selectivity of the membrane were greatly affected by the increase of suspended solids to the o/w emulsion as an increase of $1500 \mathrm{mg} \cdot \mathrm{L}^{-1}$ particulate solids to $10 \% \mathrm{v} / \mathrm{v}$ of stabilized emulsion. This led to reducing the permeability by $3.5-5$ times over different filtration experiments, compared to the emulsion alone, and a 8-36 times decrease in contrast with the suspension. Oil passage through the $0.45 \mu \mathrm{m}$ pore size of the microfiltration membrane was concomitantly increased six-fold.

\subsubsection{Hybrid and Asymmetric Membranes}

In 2018, Fard et al. [61] presented a successful PW treatment technique with a combination of inorganic membrane aluminum oxide $\left(\mathrm{Al}_{2} \mathrm{O}_{3}\right)$ in addition to activated carbon $(\mathrm{AC})$ as a low-cost adsorbent material for the adsorption process. Both $\mathrm{Al}_{2} \mathrm{O}_{3}$ and $\mathrm{AC}$ are widely available for use as inexpensive techniques. Despite the fact that inorganic membranes are generally expensive as compared to polymeric membranes, they are more able to be sterilized, autoclaved, have high temperature and wear resistance, withstanding harsh chemical cleaning and frequent backwashing, have a long lifetime, high chemical stability and a stable pore structure. The hybrid membrane exhibited very favorable results for emulsified oil and enhanced permeate flux with $96 \%$ removal efficiency. Moreover, the process enhanced the rejection of oil from the water and increased the salinity due to its destabilization of the emulsion [61].

\subsubsection{Other Emerging Membrane-Based Processes Forward Osmosis}

FO is an osmotic process that uses a semipermeable membrane to treat PW by separating it from dissolved solutes. The osmotic pressure gradient is the main factor acting as the driving force between a high (draw) and low (feed) concentration solutions (Figure 6). Moreover, the osmotic pressure gradient is important for implementing a net flow of PW within the membrane into the draw, therefore successfully concentrating the feed. The feed solution is either a dilute product stream, seawater, or a waste stream, while the draw solution is a solution particularly tailored for forward osmosis applications or a single or multiple simple salts [111]. Noteworthily, FO is usually preferred as a "pretreatment" process to directly treat feed wastewaters in view of practical water production applications [63]. The membrane support layer controls the antifouling capability of the FO membrane, which also performs the function of allowing water permeation and rejecting pollutants simultaneously. Mainly, two conditions must be included in any super-antifouling support layer, superhydrophilicity and ultra-smooth conditions, in order to reduce the hydrophobic adsorption of foulants on membrane surface. Furthermore, the ultra-smooth conditions will prevent the clogging of foulants $[63,112]$. Conventional support layers contain a tortuous 1D architecture, known as the internal concentration polarization (ICP) phenomenon. ICP functions as a stable barrier against the diffusion of water molecules and draws solute. Moreover, the construction of 3D architecture with organized pores in the membrane backing the layer will effectively overcome the ICP bottleneck [113].

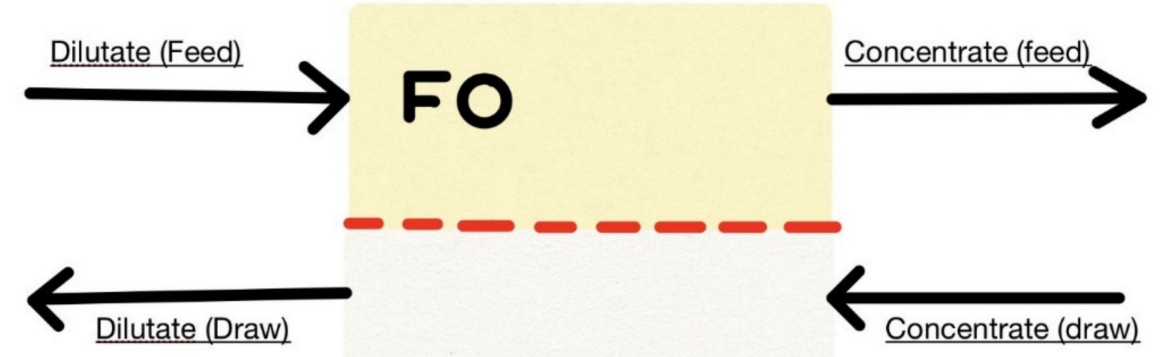

Figure 6. Forward osmosis process principle.

During 2015, Minier-Matar, et al. [50] studied a novel application of FO for decreasing the volume of PPW from oil/gas facilities. The PPW was disposed of via profound well 
injection, employing brine from thermal desalination plants as a draw solution. Bench-scale FO tests were performed using flat sheet membranes. The presented results confirmed that using pretreated PPW was successful in the implementation of FO for PW treatment as compared to non-pretreated PPW. Furthermore, FO offered an effective result of 50\% volume drop of PPW with an ordinary stable flux of $12 \mathrm{LMH}$. Different factors affect the flux of feed and draw solutions that lead to the increase in the draw solution osmotic pressure, a reduction on water viscosity, and potential improvement of some membrane properties [50]. Another study by Minier-Matar, J., et al. (2015) [51] analyzed the application of hollow fiber FO membranes for reducing the volume of PPW disposed of in onshore facilities. This work is complementary to previous work where FO was utilized as an osmotic concentration process. Flat sheet and hollow fiber FO membranes were tested, and the latter displayed better flux and rejection. Additionally, the results proved that lowenergy osmotic concentration FO has the potential for full-scale utilization to decrease PPW injection volumes. This technique is economically appropriate to decrease PPW injection volumes from Qatari-based gas facilities in an environmentally friendly manner [51]. These two studies proved the concept that osmotic concentration has the potential for full-scale fulfillment with lower energy consumption in contrast to reverse osmosis. After comparing the results, it was found that the hollow fiber membranes had a higher performance regards the constituent rejection and water flux [114]. Furthermore, using hollow fiber membranes showed higher flux with $40 \%\left(16.5 \mathrm{~L} / \mathrm{m}^{2} \cdot \mathrm{h}\right)$ after treating PPW in contrary to flat sheet membranes $\left(12 \mathrm{~L} / \mathrm{m}^{2} \cdot \mathrm{h}\right)$. Temperature showed a high influence in addition to the salinity of the draw solution [50,51].

One of the main difficulties that affect the FO process performance is membrane fouling, which was proved by using hydrophobic organics that have fouled the membranes. However, the fouling might be inhibited with successful pretreatment [50,51,53]. Regarding the quality of water, the lab study confirmed that the forward osmosis membranes are able to reject the field chemicals as well as organics existing in the feed stream, and it will not be transported to the seawater or brine utilized as draw solution. A group of studies of the osmotic concentration concept was performed to illustrate process feasibility in the field [115].

\section{Electrodialysis}

Electrodialysis is a separation process whereby charged membranes as well as electrical potential difference are employed for separating the ionic species present in an aqueous solution and other uncharged components [116,117]. The greatest advantage of this electrodialysis technology is that it can separate without any phase change, leading to comparatively lower energy utilization. This technology also has several drawbacks, such as (1) the colloids, organic matter, and silica are not separated by the electrodialysis process; (2) pretreatment of feedwater is needed for preventing the electrodialysis stacks fouling; and (3) elaborate controls are needed in this system, and maintaining them at optimal conditions could be challenging. The study by Sosa-Fernandez et al. [116] evaluated the application of pulsed electric fields during the electrodialysis of polymer-flooding produced water for improving the process performance as well as for reducing the fouling incidences. In another study by Sosa-Fernandez et al. [117], the team evaluated the separation efficiency of divalent ions present in synthetic polymer-flooding produced water by changing the operating conditions. The results confirmed that it is feasible for achieving a preferential separation of divalent cations (magnesium and calcium) by electrodialysis, particularly while using high temperature $\left(40^{\circ} \mathrm{C}\right)$ and lower current densities.

\subsection{Hydrate Inhibitors (HI)}

Chemical substances can be added to control the formation of hydrates during natural gas production in an oil or gas industry. Qatar is using HI during winter months in natural gas wells to avoid the formation of methane hydrates in the pipes, between the onshore processing facilities and offshore platforms $[55,66]$. The main two hydrate 
inhibitors are kinetic hydrate inhibitors (KHI) and thermodynamic hydrate inhibitors such as mono-ethylene glycol (MEG). KHI is usually added at lower concentrations and the chemical composition is proprietary. KHI turns as an antinucleator for delaying hydrate formation. KHI may contain polyvinyl caprolactam, polyvinyl-N-methyl acetamide, poly(vinylpyrrolidone), and polyethylacrylamide. On the other hand, MEG is typically added at higher concentrations, and can reduce the hydrate equilibrium temperature adequately to reduce hydrate formation. Qatar gas has been implemented both KHI \& MEG [118]. Janson, A., et al. (2015) [64] published a work related to the biotreatability of kinetic hydrate inhibitor $(\mathrm{KHI})$ and thermodynamic hydrate inhibitor monoethylene glycol (MEG) under set and continuous reactors in aerobic mixed-culture situations without $\mathrm{pH}$ control. The results showed that, TOC and COD exhibited more than $80 \%$ removal by biological treatment of PW with the addition of 1.5\% MEG. However, biotreatment can eliminate about $43 \%$ of TOC and COD existing in PW with the addition of $1.5 \% \mathrm{KHI}$. The feed water (with either KHI or MEG) to the reactors was at $\mathrm{pH} 4.5$ and this led to stabilizing the reactor, counted very acidic for aerobic activity, and was obviously produced by the inorganic acid via the biological culture [64]. The residual KHI in PW is considered as one of the concerns that can influence the injectivity of disposal wells [66]. In response, various processes were shown in the investigations such as chemical, physical, or biological processes to separate KHI from PW before injection to disposal wells [55]. Between the processes examined, the RO, NF, and UF membranes were estimated to be appropriate via bench-scale testing utilizing synthetic PW containing KHI [119]. KHI removal efficiency was found to be more than $99 \%$ for RO, $99 \%$ for $\mathrm{NF}$, and $83 \%$ for UF membranes. A natural gas producing company in Qatar conducted a project to remove KHI from PW using the evaporation process [18]. Since the PW includes KHI which is treated at the onshore gas operation located in Ras Laffan affects the wells, forming damage within the injection wells besides long-term effects on groundwater pollution. Redoua, A. et al. [66] (2015) used three main steps, including pretreatment, evaporation for the elimination of $\mathrm{KHI}$ and then concentrate storage, and handling. This ensured that using KHI products to prevent hydrate formations in the wells is suitable for the NG industry.

\subsection{Demulsification}

In the petroleum industry, demulsification is a process used to treat water from oil emulsion. Demulsification techniques are categorized as biological, chemical, and physical demulsification. Chemical demulsification is one of the wide separation processes used to separate oil from water. Demulsifiers are referred to as the chemicals used in this process characterized by a strong affinity to the oil-water interface. Demulsifiers are amphiphilic compounds able to abolish the stabilization through adsorbing at the interface. Mechanical strength, interfacial tension, the thickness of interfacial region, and elasticity are examples of interfacial film properties [80]. The physical demulsification processes are microwave irradiation, gravitational settling membrane separation, ultrasonic and filtration. The separation mechanism of oil and water occurs by flocculation and/or coalescence of water droplets and the demulsifiers act as one of them. One of the most important parameters in the demulsifier is hydrophilic-lipophilic balance (HLB) that shows its relative simultaneous attraction to oil and/or water phase [80].

\subsection{Coalescing}

A coalescer is a technological device using the coalescence that is applied to separate emulsions into their components through numerous processes. Coalescers are divided into two types: electrostatic coalescers, and mechanical coalescers. Electrostatic coalescers use electrical fields, direct current (DC), alternating current (AC) electric fields or both, while mechanical coalescers use filters to develop droplets coalesce. In oil/gas industries mechanical coalescers are used for the removal of water or hydrocarbon condensate [120]. Mixed flow separation, corrugated plate, interceptor, and crossflow separation are examples of equipment implemented for plate coalescence [81]. Qatar-based petroleum 
companies have applied a technology to de-oil PW to meet the standard requirements and regulations. The work was performed at both PS3 Bul-Hanine offshore field and Dukhan onshore field using TORR technology. Moreover, adsorption, coalescence, desorption, and gravity processes are used to treat the PW from dispersed oil. It has been demonstrated that coalescing elements was appropriate to de-oil most of the PW, despite the challenge in reverse emulsions that demanded modifications of the element. By changing the element's porosity and compressibility factor as well as permeability, the oil removal efficiency can be significantly improved for difficult reverse emulsions. Furthermore, the technology is effective in removing $>2 \mu$ of oil droplets [89]. One example of coalescence is the inclined multiple arc coalescence plate, which is the most favorable gravitational oil-water separators among gravitational technology. The performance of the coalescence arc plates was affected by three main factors: size, shape, and geometry [78]. Almarouf et al. (2015) [78] established an effective oil/water separator for the treatment of stable emulsions in PW, combining effects of oil droplet coalescence and chemical demulsification in order to enhance the formation of two phases for further separation. The novel oil-water separator consisted of a series of inclined multiple arc coalescence plates, and exhibited effective results in breaking stable emulsions, therefore enabling their efficient separation from produced water.

\subsection{Thermal Evaporators and Advanced Oxidation Processes (AOPs)}

Thermal evaporators are an important treatment method of PW, since they are considered as an economically feasible technique. Furthermore, the volumes of freshwater required for makeup are greatly reduced since almost all waste streams are recycled back to the evaporator [49].

\subsection{Surfactant Application}

Polyacrylamide is a polymeric surfactant, and this simple surfactant along with polymer flooding is greatly improving oil recovery. To separate water from oil, the polyacrylamide with other additives is used as destabilizing agents for water/oil emulsions, such as aluminum and ferrous sulfate. The influence of polyacrylamide on water/oil emulsion was studied through interface electric, interface strength, and interfacial tension property of oil in water wastewater process [121]. Ma, H. et al. (2016) [82] treated the PW/ oil emulsions via anionic PAMs with aluminum and ferrous sulfate as an electrolyte. The results presented that the volume of separated water enhanced more than $25 \%$ in comparison to PAMs only. Moreover, the COD viscosity and turbidity reduction of separated water improved significantly. The destabilization of water in oil emulsion was improved by using the electrolytes into polyacrylamide in general, as compared to when only polyacrylamide was used [82].

\subsection{Activated and Modified Activated Carbon Filtration ( $A C$ and $M A C$ )}

The advantage of activated carbon is it has a large surface area with changeable pore dimensions and different active sites. Activated carbon is effective in treating water by removing a large range of organic compounds, but it is not capable of removing large molecules such as humic acid that comprise emulsified grease in addition to oil. The reason is that the bigger compounds and particles plug the macroporous space on the activated carbon external surface, which makes it less effective. Activated carbon has several significant characterizations, making it one of the greatest filtration media, for instance, high adsorption ability, thermo-stability, microporous structure, high grade of surface reactivity, low acid/base reactivity, and capability for comprehensive range pollutants removal [76]. In 2010, Al-Ghouti et al. [122] presented research using activated carbon for eliminating the organosulfur compounds from the diesel-non-aqueous medium. The results showed outstanding adsorption skill of granular bead form activated carbon of organosulfur compounds from the diesel-non-aqueous medium. Moreover, the study displayed that the particle size of the activated carbon affected the organosulfur compounds 
elimination efficiency, which means that the adsorption mainly happened on the external surface area.

On the other hand, despite the fact that activated carbon is economically and obtainable resources from dates, papaya wood, dust, coconut shells, coke as well as rice husk, the modified activated carbon (MAC) has been successfully utilized as adsorbents for the removal of toxic material. Modified activated carbon has a better enhancement in the active surface for adsorbing material. This had been verified by using the waste of pods and husk; it can generate superior-quality microporous activated carbons via stratifying simple steam pyrolysis process [76]. Al-Kaabi et al. [77], in 2016, aimed to study the effect of using sand filtration, $\mathrm{AC}$, and MAC filtration by microemulsions, to remove the major organic and inorganic pollutants, BTEX, and heavy metals from PW samples. In this study, PW samples were received from the north field offshore gas. In a comparison of the three treatments, sand filtration exhibited higher removal efficiency for the TSS $(77.5 \%), \mathrm{TN}(63.7 \%)$ and corrosion inhibitor (94.1\%). Iron and manganese have the highest metals removal efficiency in addition to BTEX with $>95 \%$, with the exception of the toluene, which exhibited $26.7 \%$. It is worth mentioning that COD showed the lowest removal efficiency among the other media with only $10.2 \%$. For AC and MAC filtrations, COD was removed by $23.7 \%$ via AC, while it increased by $12.6 \%$ via MAC. Moreover, MAC was noted to be highly effective in reducing the TOC to $31.1 \%$ among the three media. From a comparison between the three treatments SF, AC, and MAC from removal efficiency point of view, it was clear that the treatments used for PW samples efficiently improved the pollutants removal efficiency to utilize it for different applications such as plant irrigation [76].

In a research study by $\mathrm{Al} \mathrm{Kaabi} \mathrm{et} \mathrm{al.} \mathrm{[123],} \mathrm{the} \mathrm{chemical} \mathrm{and} \mathrm{physical} \mathrm{characterization}$ of PW was carried out succeeded by treatment by means of sand filtration combined with activated carbon microemulsion modified activated carbon method. Figure 7 presents the schematic representation of PW treatment by means of sand filtration, as well as activated carbon [123]. The study confirmed that the treated water was free from all main contaminants of $\mathrm{PW}$, and it could be considered appropriate for reuse at domestic or industrial level.

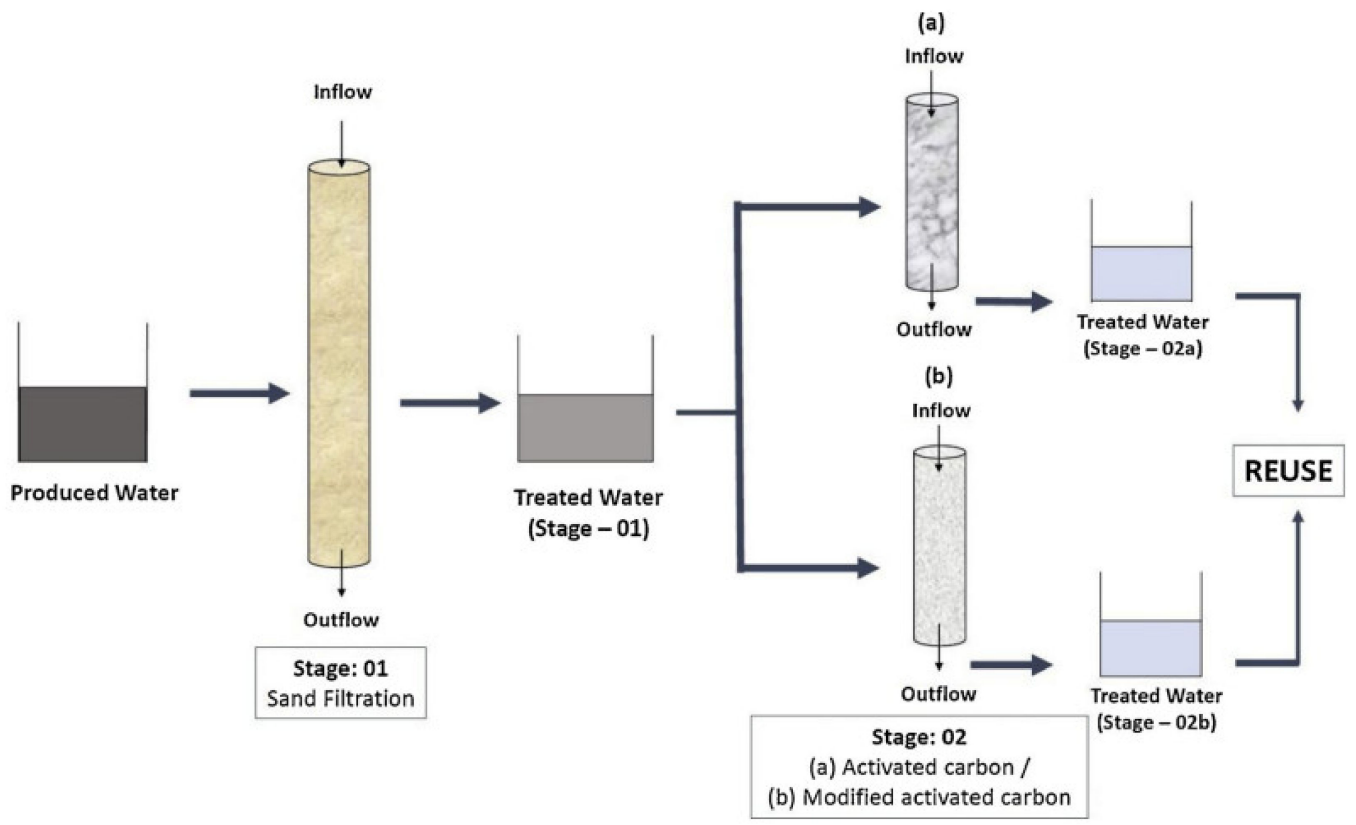

Figure 7. PW treatment by means of sand filtration as well as activated carbon. Reproduced from ref. [123].

\subsection{Adsorbents}

Application of adsorbent agents for oil-water separation showed good efficiency in the removal of heavy metals from PW, hence it is considered as a new field for further 
developments and studies. In general, CNT is a new carbon material used in many different fields. It has attracted considerable research attention owing to its thermal, chemical, mechanical stability [124]. Few studies were conducted using CNTs as adsorbent agents for oil-water separation [125]. The CNTs are characterized by exceptionally high adsorption capacity and higher hydrophobicity for oil-water separation and enhanced de-oiling processes. Fard, A. et al. [126] used iron-oxide/CNTs nanocomposites in a study for oil-water separation. The ferric oxide nanoparticles/CNTs showed mass sorption capacities for gasoline oil of up to $7 \mathrm{~g} / \mathrm{g}$.

MXene is a new adsorbent material characterized by its high adsorption capacity and efficiency in addition to its superior structural stability, hydrophilic surfaces, availability, flexibility, and high electrical conductivity. There are several studies which have been carried out on the detailed applications of MXenes for water treatment $[127,128]$. Mxene is material from a family of transition metal carbides used for water purification. It is usually synthesized by etching the first layer from MAX phases. Fard, A. and co-authors utilized Mxene as a two-dimensional (2D) nanosheet adsorbent to remove barium components from produced water. MXene (2D), titanium (III) carbide (II) $\left(\mathrm{Ti}_{3} \mathrm{C}_{2} \mathrm{~T}_{\mathrm{x}}\right)$ nanosheets were produced, and the results showed that $\mathrm{Ti}_{3} \mathrm{C}_{2} \mathrm{~T}_{\mathrm{x}}$ removed $90 \%$ of barium within $10 \mathrm{~min}$ and the adsorption of barium was $\mathrm{pH}$ dependent. MXene exhibited fast kinetics, a large sorption capacity, reversible adsorption properties, and huge trace barium removal that offer a great removal performance of barium with a capacity of $9.3 \mathrm{mg} / \mathrm{g}$ [129].

\subsection{Biological Treatments}

Amongst other traditional treatment methods, biological treatment counts as the cheapest method for the separation of contaminants. In biological treatment, anaerobic or aerobic conditions are maintained, and it is divided into three types, based on the organisms used in eliminating or removing toxic pollutants in PW such as algae, bacteria, and fungi. Virtually, the precise choice of the species, optimization, and maintenance of feeding manners, additives, and environmental conditions are the most important factors that are used to improve the treatment efficiency.

Application of microalgae is one of the eco-technology methods, where the biological treatment process accomplishes a higher rate of removing pollutants from the PW. In general, to bio-remediate produced water effluents, these microalgae are used, where they are capable of employing some of these pollutants as feed source sources of nutrients [72]. Microalgae strains are unicellular organisms employing light as sources of energy to generate biomass and $\mathrm{O}_{2}$, and due to that, they are grown in an environment with sufficient moisture and sunlight. They also hold chlorophyll-a as a photosynthetic pigment. Parachlorella Kessler, Monoraphidium sp., Neochloris sp., Chlorella sp., Scenedesmus sp., and Dictyosphaerium sp. are some example of microalgae strains used for PW and wastewater treatment. Moreover, some microalgae have a unique property in that they are able to grow in heterotrophic as well as phototrophic conditions [72]. Microalgae require dissolved carbon dioxide, trace metals, nitrogen, and phosphorus for their propagation. Despite the fact that produced water contains these elements at various concentrations, the presence of some heavy metals and toxic organic compounds could be lethal to the microalgae [130]. However, if any microalgal strain could tolerate the toxic compounds of the PW and generate sufficient biomass in it, then the method can be potentially used to supply $\mathrm{O}_{2}$ to the aerobic bacteria for the degradation of the organics. Qatar has abundant sunlight and adequate unutilized desert land which could be used for microalgal remediation of PW while producing biomass feedstock [130,131].

A study was conducted by Abdul Hakim et al. [72] in a Qatar-based university discussing a solution for pollutants removal from PW using microalgae. The PW samples collected were first filtered using a $0.45 \mu \mathrm{m}$ Millipore filter to eliminate the maximum of the TSS and other main contaminants. After that, the filtered water was employed to grow in several species of microalgae (Chlorella, Dictyosphaerium, Neochloris, Monoraphidium, and Scenedesmus) to study their abilities to remove heavy metals [72]. In this study, 
Dictyosphaerium sp., Scenedesmus sp., and Chlorella sp. presented a remarkable quantity of biomass yield among all other concentration of PW, which could be attributed to the low Cr concentration existing in the tested PW [91]. Moreover, the removal efficiency of phosphorus and other metals were high via Dictyosphaerium microalgae species, as phosphorus was removed by $88.83 \%$. Despite Neochloris sp. having low biomass generation, it removed $41.61 \%$ of TOC from the different levels of PW concentrations, and recovered $100 \%$ iron and aluminum [73]. Regarding nitrogen and BTEX removal efficiency, the results within the microalgae strains were the same. Nevertheless, the author found that the difference in PW concentration has no meaningful consequence on the pollutant's separation effectiveness of microalgae strains. Therefore, microalgae strains were able to grow and live in PW effluentsderiving from petroleum industries and separate contaminants [72,91]. In 2018, a produced water sample from a local petroleum company was collected by Das, $\mathrm{P}$ et al. [71]. The PW samples collected were first characterized and found that $\mathrm{PH}, \mathrm{TOC}, \mathrm{TN}, \mathrm{TP}$, and salinity were $4.17,720 \mathrm{ppm}, 52.5 \mathrm{ppm}, 0.21 \mathrm{ppm}$, and $4.3 \mathrm{ppt}$ respectively. $\mathrm{NaOH}$ was added as a pretreatment to raise the $\mathrm{pH}$ to 7.1 and permitted to remove $40 \%$ of TOC, $38.3 \%$ of $\mathrm{TN}$, and $19 \%$ of TP [71]. However, the authors found that pretreated produced water was still toxic for some of the local microalgae strains, and even for zebrafish. Thereafter, two conditions were studied for the growing viability of three freshwaters and three marine microalgae strain in the pretreated PW. The first condition was studying the six microalgae strains without additional nutrients, and the second condition was adding $\mathrm{N}$ and $\mathrm{P}$. Of these strains, only Scenedesmus sp. and Chlorella sp. were able to grow in both conditions. Chlorella sp. was able to reach the highest biomass yield in the nutrient-supplemented pretreatment PW with 1.2-g L ${ }^{-1}$. Furthermore, as the pretreated PW was supplemented with nitrogen and phosphorus, Chlorella sp. biomass yield increased more and simultaneously removed $73 \%$ of TOC, $92 \%$ of TN, and other heavy metals. In this research, all the zebrafish managed to survive for at least nine days in the Chlorella sp. remediated produced water [71].

\subsection{Electrocoagulation (EC)}

Electrocoagulation has received extensive attention in the last several years as a green and one of the effective electrochemical techniques for water treatment. It possesses numerous advantages over traditional PW treatment techniques, such as the capability of treating oily water, generating less sludge, and eliminating chemical additives [68]. EC presented its ability in dealing with several pollutants such as organic and inorganic contaminants with higher efficiency without any by-product wastes. This technique combines the advantages of coagulation, electrochemistry, and flotation. In EC, a chemical reaction occurs due to the movement of an electric current through an electrolyte that exists between two electrodes: cathode and anode [67]. EC essentially aims to remove the pollutants from water through electrocoagulation, electro flocculation, electro-oxidation, destabilizing as well as neutralizing the repulsive forces among the suspended particles. When one of the repulsive forces is neutralized, it will lead to forming bigger suspended particles, and thus fall, which makes this technique unique in comparison with other processes [69]. In 2018, Aly, D. [68] developed a new cell to mitigate the cathode passivation problems via using several types of metal ( $\mathrm{Al}$ and $\mathrm{Fe}$ ) and perforated hollow cylindrical cathode for the cell electrode. The cathode electrode was used with compressed air allowed to flow from cathode perforations to clean the electrode and provide a sufficient mixing. The results of the new cell design showed a higher removed efficiency of organic contaminants with about $96.8 \%$ for TOC, $97.9 \%$ for TPH, and $94.6 \%$ O\&G. As a consequence, this design was found to be more effective in treating PW and minimizing cathode passivation compared with other basic electrocoagulation setups with plate electrodes [68].

\subsection{Steel Slag Treatment}

Steel slag is considered as a by-product manufactured during the steel separation process. The steel is molten to liquid metals and then solidified, leading to the creation 
of metal oxides and silicate solids. Furthermore, it contains $\mathrm{CaO}, \mathrm{Fe}_{2} \mathrm{O}_{3}$ and other metals such as silicate, $\mathrm{Mn}$, and $\mathrm{Mg}$ materials. Nowadays, steel is made by two technologies, namely electric arc blast and the oxygen steel convertor process. The characteristics and qualities of slag steel are ranging from low to high depending on its disposal location. Qatar-based steel companies manufacture approximately 400,000 tons of slag annually. This high level of production will result in the problem of recyclability or disposal of slag from the company. Hence, one of the solutions is to use steel slag in the electrocoagulation process for treating the produced water [69].

In 2017, Al-ghoul, M and Al Haawari, A. [69] used steel slag as a supplementary coagulant in the electrocoagulation process as a treatment for PW. After the application of $10 \mathrm{~mA} / \mathrm{cm}^{2}$ current density at 10 minutes' reaction time, results showed that the slag sample had a TSS removal efficiency of $90 \%$ in comparison with a pure sample of $55.7 \%$. Moreover, the ability of the slag sample to remove the turbidity reached $85.9 \%$, while the pure sample presented $80.1 \%$ removal efficiency. It has been demonstrated that increasing the reaction time led to an increase in the removal efficiency both TSS and turbidity to a certain extent. It was found that at a reaction time of $30 \mathrm{~min}$, the optimum removal percentage was obtained. The slag sample showed $94.8 \%$ for TSS and $92.5 \%$ for turbidity removal percentages, and $90 \%$ TSS and $90.3 \%$ turbidity for the pure sample. The removal efficiency for oil and grease analysis for the samples with and without steel slag showed almost same result, around $98.9 \%$ [69].

\section{Case Studies of PW Treatment in Qatar}

Several case studies have been carried out in Qatar for the effective treatment of PW. The PW from one of the NG fields based in Qatar was obtained by the group of Al-Ghouti et al. [91]. This PW was employed for examining the separation of heavy metals employing microalgae. As presented in Table 7, complete separation (100\%) of Fe and $\mathrm{Al}$ from PW was accomplished using microalgae, whereas $\mathrm{K}$ demonstrated the least separation efficiency $(11.27 \%)$.

Table 7. Separation of trace metals from PW employing microalgae. Reproduced from Ref. [91].

\begin{tabular}{ccccc}
\hline Trace Metals & Filtered Water $(\mathbf{p p b})$ & Feed Water $(\mathbf{p p b})$ & \% Removal & Microalgae Species \\
\hline $\mathrm{Cd}$ & 0.06 & 0.09 & 97.37 & Chlorella \\
$\mathrm{Ni}$ & 3.71 & 7.83 & 92.29 & Dictyosphaerium \\
$\mathrm{Cr}$ & 17.2 & 24.09 & 19.36 & Dictyosphaerium $\mathrm{sp}$. \\
$\mathrm{Fe}$ & 100.19 & 287.94 & 100 & Neochloris sp.; Chlorella sp. \\
$\mathrm{Mn}$ & 318.56 & 318.56 & 87.8 & Neochloris sp. \\
$\mathrm{Sr}$ & $105.73 \times 10^{2}$ & $111.98 \times 10^{2}$ & 21.23 & Dictyosphaerium $\mathrm{sp}$. \\
$\mathrm{K}$ & $677.40 \times 10^{2}$ & $736.18 \times 10^{2}$ & 11.27 & Scenedesmus sp. \\
$\mathrm{Ba}$ & 43.35 & 55.69 & 13.06 & Monoraphidium sp. \\
$\mathrm{V}$ & 1.46 & 1.87 & 36.26 & Scenedesmus \\
$\mathrm{Al}$ & 13.68 & 114.41 & 100 & Neochloris sp. \\
$\mathrm{Mg}$ & $392.57 \times 10^{2}$ & $417.15 \times 10^{2}$ & 13.9 & Dictyosphaerium $\mathrm{sp.}$ \\
$\mathrm{Cu}$ & 180.78 & 224.97 & 91.65 & Dictyosphaerium $\mathrm{sp}$. \\
$\mathrm{B}$ & $374.7 \times 10^{2}$ & $425.9 \times 10^{2}$ & 20.23 & Dictyosphaerium sp. \\
\hline
\end{tabular}

Shaikh, S. et al. [74] studied the heavy metal accumulation, microbial succession, and germination tests for turf grass seeds and weeds for evaluating the impacts of PW irrigation. PW was used to irrigate turfgrass-Cynodon dactylon and Paspalum sp. The samples were collected from Total Qatar, sourced from their station at the Halul Island. According to the C. dactylon results, it showed lower tolerance capacity towards PW in comparison with Paspalum sp. which exhibited better tolerance by withstanding at least withstand $30 \%$ PW and $4.5 \%$ salinity. As a consequence, Paspalum sp. was more capable of being used in Qatar's areas that are planned to be irrigated with produced water. The Ministry of Qatar has already used Paspalum sp. as turf grass around Qatar's parks, roadsides, and golf courses, which can allow for the use of PW for their growth [6]. Moreover, studying the microbial succession depicted that produced water irrigation had resulted in variation in the fungal species, especially in $10 \%$ of produced water and $30 \%$ of PW-treated soil, 
and were absent in soil treated with tap water. The effect of concentration of produced water (L-R, $0 \%$ (tap water) up to $100 \%$ produced water) on turf grass (Cynodon dactylon) coverage (\%) after being subjected to 14 weeks of treatment was studied. In general, the concentration of PW used for irrigation is the key to determine the effect of weeds and turf grass growth besides their abundance [74].

In a study by Al Kaabi et al. [123], PW samples from gas production process situated in Qatar north field were gathered, characterized, as well as treated. The characterization results demonstrated that the PW had high TOC and chemical oxygen demand (COD) values, i.e., 2405 and 10,496 ppm, respectively, and higher contents of benzene, toluene, ethylbenzene, and xylene (BTEX), and other metals. Table 8 presents the PW characterization from the north offshore gas field, Qatar. The results of organic compounds such as the benzene were available in maximum concentrations $(11,170 \mathrm{ppb})$, succeeded by ethylbenzene (4648.6 ppb), xylene (1156.8 ppb), and toluene (378.1 ppb). After the treatment, sand filtration demonstrated the greatest removal efficiency for corrosion inhibitors (94.1\%) and TSS $(77.5 \%)$, which is due to the straining mechanisms. The highest removal efficiency of metals was for manganese and iron and was also able to separate BTEX.

Table 8. PW characterization from north offshore gas field, Qatar. Reproduced from ref. [123].

\begin{tabular}{|c|c|c|c|}
\hline Parameters & Mean Values & Parameters & Mean Values \\
\hline \multicolumn{2}{|c|}{ Major parameters } & \multicolumn{2}{|c|}{ Metals } \\
\hline TSS (ppm) & $21.34 \pm 3.51$ & Strontium (ppb) & $13,181 \pm 114$ \\
\hline $\mathrm{pH}$ & $4.43 \pm 0.01$ & Vanadium (ppb) & $2.55 \pm 0.04$ \\
\hline Conductivity & $7035 \pm 56$ & Sodium (ppb) & $1,198,167 \pm 16,526$ \\
\hline COD (ppm) & $10,496 \pm 162$ & Zinc (ppb) & $4.97 \pm 0.28$ \\
\hline Salinity (ppt) & $4502 \pm 36$ & & \\
\hline $\mathrm{BOD}(\mathrm{ppm})$ & $1034 \pm 42$ & \multicolumn{2}{|c|}{ Other pollutants } \\
\hline TOC (ppm) & $2405 \pm 16$ & Propionate (ppm) & $17.37 \pm 1.04$ \\
\hline & & $\% \mathrm{KHI}$ & $0.27 \pm 0.05$ \\
\hline Ethyl benzene (ppb) & $4648 \pm 688$ & Phenol (ppm) & $1.96 \pm 0.07$ \\
\hline Xylene $(\mathrm{ppb})$ & $1156 \pm 88$ & HEM (ppm) & $40.54 \pm 4.20$ \\
\hline Benzene (ppb) & $11,170 \pm 4298$ & Formate (ppm) & $0.35 \pm 0.04$ \\
\hline Toluene (ppb) & $278.2 \pm 14.3$ & Corrosion Inhibitor (ppm) & $623.3 \pm 15.5$ \\
\hline & & Acetate (ppm) & $368.7 \pm 4.04$ \\
\hline Potassium (ppb) & $100,922 \pm 122$ & $\mathrm{TN}(\mathrm{ppm})$ & $47.41 \pm 0.25$ \\
\hline Nickel (ppb) & $7.08 \pm 0.28$ & \% MEG & $0.33 \pm 0.07$ \\
\hline Molybdenum (ppb) & $5.52 \pm 0.02$ & \multicolumn{2}{|c|}{ Other Ions } \\
\hline Manganese (ppb) & $258.3 \pm 2.7$ & Sulfide (ppm) & $326.3 \pm 21.1$ \\
\hline Iron (ppb) & $4144 \pm 114$ & Sulphate (ppm) & $46.13 \pm 0.19$ \\
\hline Aluminum (ppb) & $10.28 \pm 6.75$ & Silica (ppm) & $2.0 \pm 0.1$ \\
\hline Arsenic (ppb) & $7.24 \pm 1.89$ & Phosphate (ppm) & $2.06 \pm 0.08$ \\
\hline Chromium (ppb) & $30.31 \pm 0.37$ & Magnesium (ppb) & $45,064 \pm 1223$ \\
\hline Barium (ppb) & $60.51 \pm 0.45$ & Chloride (ppm) & $2921 \pm 10$ \\
\hline Cobalt (ppb) & $7.04 \pm 0.70$ & Boron (ppb) & $5744 \pm 95$ \\
\hline Copper (ppb) & $0.62 \pm 0.05$ & Calcium (ppb) & $285,565 \pm 2205$ \\
\hline Cadmium (ppb) & $0.05 \pm 0.01$ & & \\
\hline
\end{tabular}

In another study by Atia, F. et al. [75], the team collected the soil from the Mesaieed area in Qatar, and seeds of the crop plant species from the local market, seedlings of Phragmitis. sp. from El-Khour area (north of Doha) and Salsola. sp. from the biology field of a Qatar-based university campus. Their PW samples were provided by an oil and gas company in Qatar, and the team used it at different dilution percentages for plant irrigation $(0,10,20,30,40,50 \%)$ in the greenhouse for Zea mays, Medicago sativa, Sorghum bicolor, Helianthus Annuus, Salsola baryosma and Phragmites australis. The PW samples were chemically and physically characterized, and the results presented higher content of chloride, boron ions, sodium, sodium adsorption, and TDS ratio as 122, $0.038 \mathrm{~g} / \mathrm{L}, 61,139.9$, and $300 \mathrm{meq} / \mathrm{L}$, respectively. Among all plants, Medicago sativa was the only survivor which tolerated $10.0 \%$ produced water with a reduction in length, intensity, and biomass to reach 
to $33 \%$. Furthermore, Salsola baryosma tolerated irrigation of PW 20.0\% without any remarkable variations in the morphological characteristics. After that level, the heavy metals accumulation and morphological growth were completely disturbed. It has been demonstrated that the soil showed a huge enhancement in salinity, as well as sodium adsorption ratio (SAR) levels which interfered with the soil physical characteristics affecting the permeability and water flow. Figure 8 presents the comparison between the development of root and shoot of alfalfa at $10 \%$ produced water irrigation, having been irrigated using tap water. It was noted that there was no remarkable variation in the root growth under $10 \%$ produced water irrigation, whereas the shoot growth showed remarkable difference. Carbon accumulation percentage is related with the organic accumulation. From control to 10 and $20 \% \mathrm{PW}$, it can be noted that the accumulation is smooth and slowly improves, while it has sharpness at $30 \%$ PW (Figure 9). Moreover, in the study, it was noted that the organic contents of produced water were below detection limits of ultra-performance liquid chromatography (UPLC), as well as gas chromatography (GC) instruments after dilutions at altered levels [75].

Onwusogh, U. et al. [65] presented some treatments technologies to treat and reuse the PW from onsite effluent treatment plant (ETP). Among different type of treatments, the biotreatment, crystallization and evaporation processes, flocculation, flotation, membrane filtration (included submerged Ultrafiltration (sUF) and RO units), and catalytic wet air oxidation (cWAO) were used for cooling and power generation. According to the results, all of the treatments enhanced the removal efficiency of most of the pollutants from PW. It is worth mentioning that cWAO is effective in removing $\mathrm{KHI}$ and delivers a high quality of suitable water for treatment in onsite ETP. All PW samples were obtained from the gas field. The characterization of organic and inorganic components illustrated that the concentration of chloride $(\mathrm{Cl})$ was the highest reached about $1237 \mathrm{mg} / \mathrm{L}$, followed by sodium (Na), and calcium (Ca) with approximately the same concentration 424 and $386 \mathrm{mg} / \mathrm{L}$, respectively. Moreover, the concentration of sulfur $(\mathrm{S})$, sulfate $\left(\mathrm{SO}^{-2}{ }_{4}\right)$, potassium $(\mathrm{K})$ and magnesium $(\mathrm{Mg})$ were almost similar to each other with values almost $45 \mathrm{mg} / \mathrm{L}$. Boron (B), silica (Si), strontium ( $\mathrm{Sr}$ ), and iron (Fe) showed poor values. The GTL plant mentioned in this case studied generated up to $400 \mathrm{~m}^{3}$ / day of PW consisting of $1.5 \mathrm{wt} \%$ of KHI solution. The total dissolved solids (TDS) concentration was noted to be between 3000 to 5000 ppm [65].

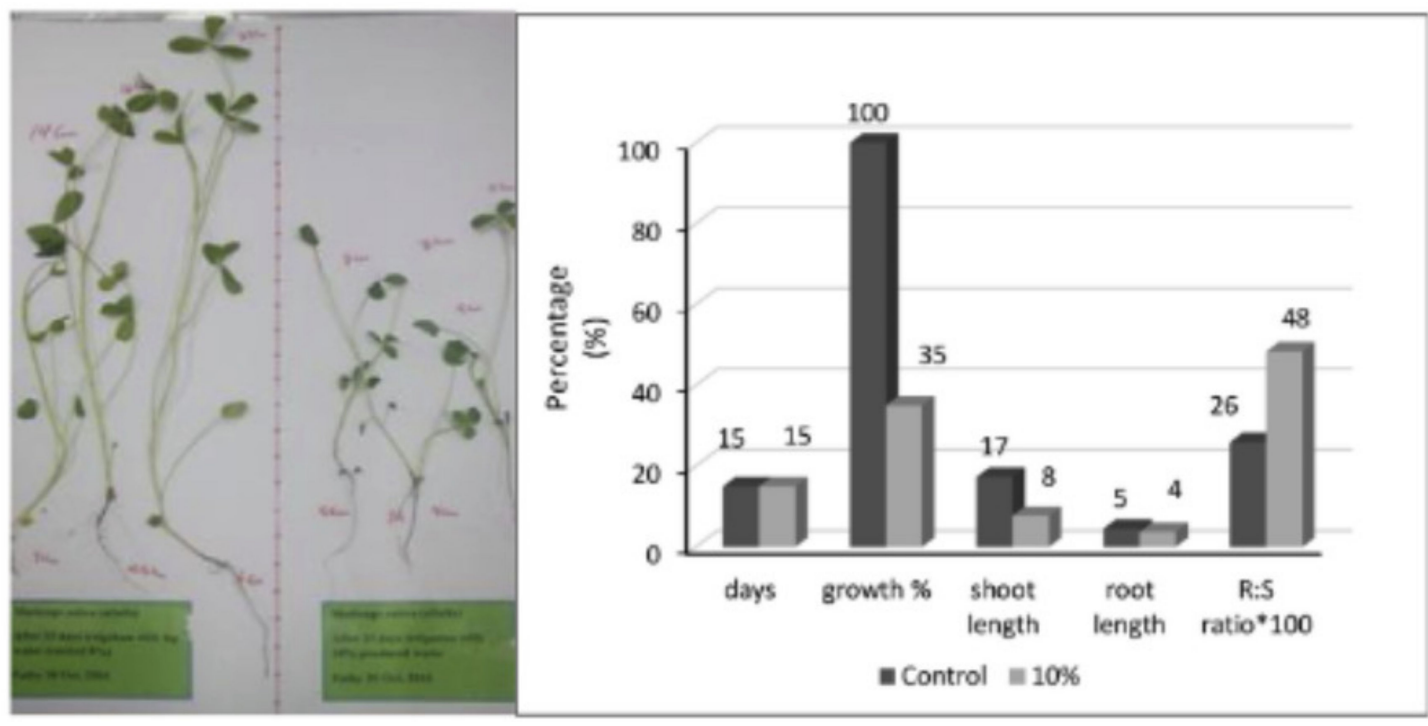

Figure 8. Alfalfa irrigated with tap water and 10\% PW after 15 days. Reproduced from Ref. [75]. 


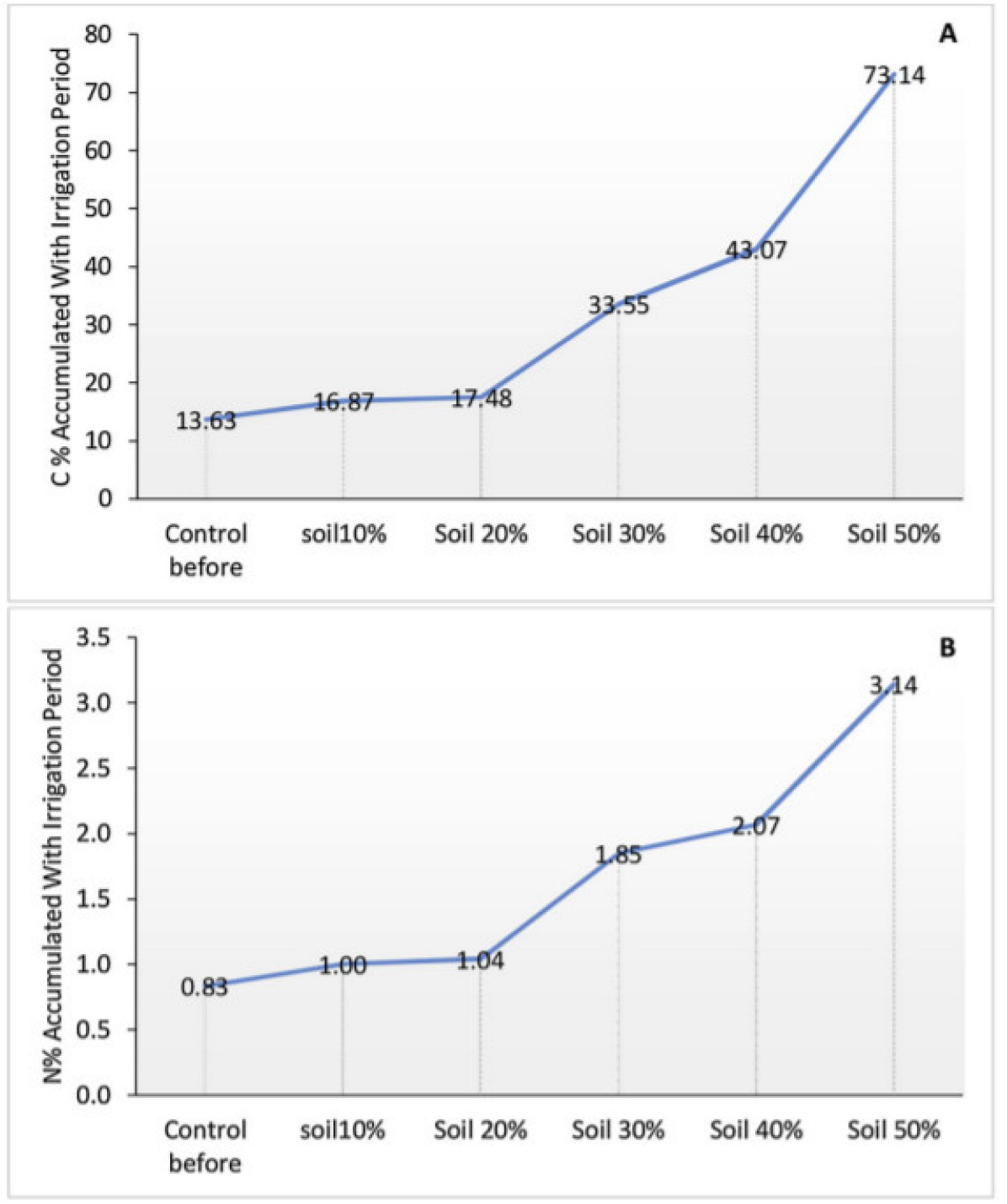

Figure 9. (A) Carbon \% accumulation in the soil with produced water irrigation and (B) nitrogen \% accumulation in the soil. Reproduced from ref. [75].

\section{Future Outlook}

Recently, several advanced technologies or series of technologies developed for treating the PW have been presented. Certain technologies are entirely new, whereas others have been modified from several other municipal or commercial wastewater process operations or treatments. PW management is substantially important for the economic and safe production of gas and oil. The application of online oil-in-water monitors could perform an important role in manufacturing process control, as well as the optimization, discharge reporting, and injection of water quality checks. With the technological developments, an upgraded perception, and a proper understanding of the doubts related to the existing sampling, as well as measurement routine, together with the continuous efforts from industry, an increased use of online oil-in-water monitors can be noted for the PW management.

Moreover, the difference in PW treatment technologies, the effect of numerous constituents of produced water on the agriculture, re-injection in oil/gas industry, or on the growth of microalgae need to be investigated further. The proper characterization step of PW for determining the major components is recommended as the initial step for selecting the finest treatment options. The characterization results will determine whether physical, thermal, or chemical treatments are adopted. Moreover, it is also recommended to adopt 
the zero liquid discharge concept, thereby avoiding any extra contaminant stream generation and thus waste minimization. Presently, there are specific PW treatment technologies; however, most of the technologies are tailor-made for meeting the specific treatment requirements for each site, and typically concentrate on just a particular group of PW hazardous elements [132].

The National Development Strategy as well as Qatar Vision 2030 both realize the requirement for good water management for sustaining the quick growth of Qatar, in spite of the shortage in natural freshwater. They take active engagement in bringing several diverse water stakeholders collectively for a sustainable future. In 2010, ConocoPhillips started the Global Water Sustainability Center for studying the technology associated with the PW, as well as desalination. This center in Qatar research aimed to develop advanced and economic solutions to treat as well as recycle PW from the oil and gas industries and contributing support to Qatargas.

\section{Current Challenges and Environmental Issues of Produced Water}

The immense amount of PW water discharged each year offers an ecological problem to the industries. Due to the importance of PW, the adequate treatments of it have been approached to be very critical to reuse or discharge PW to the environment. Therefore, the present major challenge in oil and gas companies have become to be the exploration of an effective and inexpensive treatment method for minimizing the pollutants present in the PW for discharging or/and reusing the constitutes. In the oil and gas industry, approximately 3 to 10 barrels of produced water are brought to the surface for every barrel of oil produced. All of the dispersed oil, heavy metals, large amounts of organic material, inorganic salts, and high levels of sulfur and sulfides present in PW are of particular environmental concern. Therefore, reducing the hazardous waste of PW before discharging it to the environment becomes essential. In the event that the PW was not carefully managed, such as releasing it to neighboring surface water bodies without proper treatments or allowing it to soak into the ground, massive ecological damage will occur. Nevertheless, industries are following reliable programs of activities to prevent the ecological damage. As an illustration, the offshore discharges, even properly treated, will offer certain impacts, although moderate, such as increased pollutant levels and reduced oxygen in the nearby fields. One of the most important objectives of environmental monitoring is to evaluate if the discharge regulations are sufficiently protective. Hence, several physical treatments were used to clean the PW before the discharge in addition to the regulations added to frontier on levels of contaminants, which can be discharged to the sea. Moreover, to moderate the discharge of PW, reinjection has been used for many years. In the case of majority open water situations, the quantity of local dilutions as well as the currents that stimulate dispersion lessens the possible effects very rapidly. In the nearby shore settings, emissions from offshore platforms can offer a significant impact, and generally zero discharge is needed in these regions. However, if some other water managing practice were utilized, it may have a lesser water impact however can have a more energy use impact.

Other major challenges of produced water are the generation of hazardous sludge in chemical treatment, the consequent disposal problems, the sensitivity to the initial concentration of wastewater, higher operation expenses, potential chronic toxicity of the treated $\mathrm{PW}$, high treatment cost, and public acceptance. Moreover, the sensitivity to variation of organic chemicals in biological treatment is another major challenge for treating $P Q$, besides the salt concentration of influent waste. Furthermore, the quantity and characteristics of the PW varies over time, making a "one size fits all" solution unlikely.

With regards to oil and gas PW, the treatment expense effectively depends on the chemical and physical properties of the PW, which could differ extensively in the production fields and vary over time in a specific field, as well as the monitoring environment. As an illustration, the PW from gas field, particularly coalbed methane production, usually has low total dissolved solids, grease content, and oil, as compared to that from oil production. Hence, the proper treatment of PW can possibly be competitive as compared to 
other wastewater sources. Although current technologies are proven to meet the present standards of drinking water [132], there are several anxieties concerning the unidentified poisonous effects or undiscovered hazardous compounds. Until the human health impacts of chemical compounds are well understood, toxicity assays are required for addressing any matters on the possible synergy between hazardous compounds and the probability of unobserved hazardous compounds in the treated PW.

\section{Reuse of Produced Water}

Treated produced water can be reused in various applications, such as in increasing oil production by underground injection, irrigation, livestock or wildlife watering, and various industrial uses. Al-Kaabi et al. [77] mentioned in their study, the demand for a design to adopt an environment-friendly method, for instance, phytoremediation to separate more contaminants from PW and soil to reuse it in the Qatari landscape and biofuel plantation. The technological solutions for drinkable reuse of PW will require it to be adapted as per the properties of the PW and the quantity of water to be treated. Due to the need for desalination as well as the separation of huge quantity of organic compounds, the reverse osmosis technology will most probably be employed for drinking reuse applications. Even though $\mathrm{RO}$ is capable of removing many organic compounds with increased efficiency, the combined chronic toxicity of the organic compounds present in the mixture in the reverse osmosis permeate should be thoroughly assessed prior to its direct reuse is executed. A technique for confirming maximal safe pollutant concentrations based on mixed impact of the pollutant mixture is necessary.

The benefit of using membrane process to treat and reuse PW have been studied successfully in many field studies. The study by Al Kaabi et al. [123] confirmed that the treated water was free from all main contaminants of PW, and it could be considered appropriate for reuse at domestic or industrial level. Furthermore, the Gas Processing Center (GPC) in Qatar University contributes to meeting the challenge of huge volume discharge of PW by developing advanced treatment approaches for achieving a zero harmful release in oil and gas production, and to permit the economic reuse of PW generated at the time of field operations.

\section{Conclusions}

As produced water is wastewater generated during the gas and oil production process, this water is typically trapped during subsurface formations, and is brought to the surface along with oil or gas to maintain reservoir pressure. The presence of pollutants, heavy metals, and toxic organic compounds in PW attract the attention of researchers to find an effective solution to treat this water. Qatar is one of the most water-stressed countries in the world, with relatively very limited freshwater resources, and therefore, the proper treatment of PW has turned out to be critical to reuse or discharged to the environment.

The present study highlighted the generation of produced water in Qatar, the PW characteristics in detail, and the physical, chemical, and biological treatment techniques for the PW. In the end, case studies from different companies in Qatar and the challenges of treating the produced water are discussed. From the different studies analyzed, various techniques, as well as sequencing of different techniques, were noted for the employment for the treatment of PW. In the oil and gas industry, approximately 3 to 10 barrels of produced water are brought to the surface for every barrel of oil produced. Therefore, researchers and companies detailed in their works and literature review that the characteristic of produced water varies from area to area, and thus the treatment technologies also vary for obtaining the fresh water. The proper characterization step of PW for determining the major components is recommended as the initial step for selecting the finest treatment options. It is also recommended that the zero liquid discharge concept is adopted, thereby avoiding any extra contaminant stream generation and thus waste minimization. The sensitivity to variation of organic chemicals in biological treatment is another important challenge to treat PW, alongside the salt concentration of influent waste. Although the 
present technologies are proven to meet the present standards of drinking water, there are still several anxieties concerning the unidentified poisonous effects or undiscovered toxic compounds. The aims of the largest LNG producer in Qatar are aligned with of the Ministry of Municipality and Environment (MME) in maximizing the use of water and reducing wastewater discharge. There are an increasing number of membrane-based studies in Qatar for effective water treatment. However, different factors such as high initial capital costs of some PW treatment technologies, restrict an overall recommendation for treating produced water. Furthermore, the vast oil/gas and petrochemicals industry production requires a huge amount of water to be used in the industrial processes, driving a further emphasis on water use and resources.

Funding: This research received no external funding.

Institutional Review Board Statement: Not applicable.

Informed Consent Statement: Not applicable.

Data Availability Statement: Some or all data that support the findings of this study are available from the corresponding author upon reasonable request.

Acknowledgments: This publication was supported by Qatar University Grant QUEX-CAM-QPPW-18/19.

Conflicts of Interest: The authors declare no conflict of interest.

\section{References}

1. Khader, E.H.; Mohammed, T.J.; Mirghaffari, N.; Salman, A.D.; Juzsakova, T.; Abdullah, T.A. Removal of organic pollutants from produced water by batch adsorption treatment. Clean Technol. Environ. Policy 2021, 23, 1-8. [CrossRef]

2. Alzahrani, S.; Mohammad, A.W. Challenges and trends in membrane technology implementation for produced water treatment: A review. J. Water Process Eng. 2014, 4, 107-133. [CrossRef]

3. Dickhout, J.M.; Moreno, J.; Biesheuvel, P.M.; Boels, L.; Lammertink, R.G.H.; De Vos, W.M. Produced water treatment by membranes: A review from a colloidal perspective. J. Colloid Interface Sci. 2017, 487, 523-534. [CrossRef] [PubMed]

4. Mao, S.; Deng, Y.; Pelusi, D. Alternatives selection for produced water management: A network-based methodology. Eng. Appl. Artif. Intell. 2020, 91, 103556. [CrossRef]

5. Alammar, A.; Park, S.H.; Williams, C.J.; Derby, B.; Szekely, G. Oil-in-water separation with graphene-based nanocomposite membranes for produced water treatment. J. Membr. Sci. 2020, 603, 118007. [CrossRef]

6. Ganiyu, S.O.; Sable, S.; El-Din, M.G. Advanced oxidation processes for the degradation of dissolved organics in produced water: A review of process performance, degradation kinetics and pathway. Chem. Eng. J. 2021, 429, 132492. [CrossRef]

7. Hendges, L.T.; Costa, T.C.; Temochko, B.; González, S.Y.G.; Mazur, L.P.; Marinho, B.A.; da Silva, A.; Weschenfelder, S.E.; de Souza, A.A.U.; de Souza, S.M.G.U. Adsorption and desorption of water-soluble naphthenic acid in simulated offshore oilfield produced water. Process Saf. Environ. Prot. 2021, 145, 262-272. [CrossRef]

8. McLaughlin, M.C.; Blotevogel, J.; Watson, R.A.; Schell, B.; Blewett, T.A.; Folkerts, E.J.; Goss, G.G.; Truong, L.; Tanguay, R.L.; Argueso, J.L.; et al. Mutagenicity assessment downstream of oil and gas produced water discharges intended for agricultural beneficial reuse. Sci. Total Environ. 2020, 715, 136944. [CrossRef]

9. Babu, P.; Bollineni, C.; Daraboina, N. Energy Analysis of Methane-Hydrate-Based Produced Water Desalination. Energy Fuels 2021, 35, 2514-2519. [CrossRef]

10. Ali, S.; Ijaola, A.O.; Asmatulu, E. Multifunctional water treatment system for oil and gas-produced water. Sustain. Water Resour. Manag. 2021, 7, 89. [CrossRef]

11. Madadizadeh, A.; Sadeghein, A.; Riahi, S. A Comparison of Different Nanoparticles' Effect on Fine Migration by Low Salinity Water Injection for Oil Recovery: Introducing an Optimum Condition. J. Energy Resour. Technol. 2021, 144, 013005. [CrossRef]

12. Tale, F.; Kalantariasl, A.; Malayeri, M.R. Estimating transition time from deep filtration of particles to external cake during produced water re-injection and disposal. Part. Sci. Technol. 2021, 39, 312-321. [CrossRef]

13. Wang, Y.; Yu, M.; Bo, Z.; Bedrikovetsky, P.; Le-Hussain, F. Effect of temperature on mineral reactions and fines migration during low-salinity water injection into Berea sandstone. J. Pet. Sci. Eng. 2021, 202, 108482. [CrossRef]

14. Zheng, J.; Chen, B.; Thanyamanta, W.; Hawboldt, K.; Zhang, B.; Liu, B. Offshore produced water management: A review of current practice and challenges in harsh/Arctic environments. Mar. Pollut. Bull. 2016, 104, 7-19. [CrossRef]

15. Torres, L.; Yadav, O.P.; Khan, E. A review on risk assessment techniques for hydraulic fracturing water and produced water management implemented in onshore unconventional oil and gas production. Sci. Total Environ. 2016, 539, 478-493. [CrossRef]

16. Sosa-Fernandez, P.; Miedema, S.; Bruning, H.; Leermakers, F.; Post, J.; Rijnaarts, H. Effects of feed composition on the fouling on cation-exchange membranes desalinating polymer-flooding produced water. J. Colloid Interface Sci. 2021, 584, 634-646. [CrossRef] 
17. Simona, C.; Raluca, I.; Anita-Laura, R.; Andrei, S.; Raluca, S.; Bogdan, T.; Elvira, A.; Catalin-Ilie, S.; Claudiu, F.R.; Daniela, I.-E.; et al. Synthesis, characterization and efficiency of new organically modified montmorillonite polyethersulfone membranes for removal of zinc ions from wastewasters. Appl. Clay Sci. 2017, 137, 135-142. [CrossRef]

18. Su, Y.N.; Lin, W.S.; Hou, C.H.; Den, W. Performance of integrated membrane filtration and electrodialysis processes for copper recovery from wafer polishing wastewater. J. Water Process. Eng. 2014, 4, 149-158. [CrossRef]

19. Eljamal, O.; Jinno, K.; Hosokawa, T. Modeling of solute transport and biological sulfate reduction using low cost electron donor. J. Environ. Geol. 2009, 56, 1605-1613. [CrossRef]

20. Maamoun, I.; Eljamal, O.; Falyouna, O.; Eljamal, R.; Sugihara, Y.J.W.S. Stimulating effect of magnesium hydroxide on aqueous characteristics of iron nanocomposites. Water Sci. Technol. 2019, 80, 1996-2002. [CrossRef]

21. Chekioua, A.; Delimi, R. Purification of $\mathrm{H}_{2} \mathrm{SO}_{4}$ of pickling bath contaminated by Fe (II) ions using electrodialysis process. Energy Procedia 2015, 74, 1418-1433. [CrossRef]

22. Tristán Teja, C.; Fallanza Torices, M.; Ibáñez Mendizábal, R.; Ortiz Uribe, I. Reverse electrodialysis: Potential reduction in energy and emissions of desalination. Appl. Sci. 2020, 10, 7317. [CrossRef]

23. Căprărescu, S.; Zgârian, R.G.; Tihan, G.T.; Purcar, V.; Totu, E.E.; Modrogan, C.; Chiriac, A.-L.; Nicolae, C.A. Biopolymeric membrane enriched with chitosan and silver for metallic ions removal. Polymers 2020, 12, 1792. [CrossRef]

24. Caprarescu, S.; Radu, A.L.; Purcar, V.; Sarbu, A.; Vaireanu, D.I.; Ianchis, R.; Ghiurea, M. Removal of copper ions from simulated wastewaters using different bicomponent polymer membranes. Water Air Soil Pollut. 2014, 225, 2079. [CrossRef]

25. Obotey Ezugbe, E.; Rathilal, S. Membrane technologies in wastewater treatment: A review. Membranes 2020, 10, 89. [CrossRef]

26. Eljamal, R.; Eljamal, O.; Maamoun, I.; Yilmaz, G.; Sugihara, Y. Enhancing the characteristics and reactivity of nZVI: Polymers effect and mechanisms. J. Mol. Liq. 2020, 315, 113714. [CrossRef]

27. Osama, E.; Junya, O.; Kazuaki, H. Removal of phosphorus from water using marble dust as sorbent material. J. Environ. Prot. Sci. 2012, 2012, 21755.

28. Abd Halim, N.S.; Wirzal, M.D.H.; Hizam, S.M.; Bilad, M.R.; Nordin, N.A.H.M.; Sambudi, N.S.; Putra, Z.A.; Yusoff, A.R.M. Recent development on electrospun nanofiber membrane for produced water treatment: A review. J. Environ. Chem. Eng. 2021, 9, 104613. [CrossRef]

29. Liang, H.; Zou, C.; Tang, W. Development of novel polyether sulfone mixed matrix membranes to enhance antifouling and sustainability: Treatment of oil sands produced water (OSPW). J. Taiwan Inst. Chem. Eng. 2021, 118, 215-222. [CrossRef]

30. Weschenfelder, S.E.; Fonseca, M.J.C.; Borges, C.P. Treatment of produced water from polymer flooding in oil production by ceramic membranes. J. Pet. Sci. Eng. 2021, 196, 108021.

31. Wu, M.; Zhai, M.; Li, X. Adsorptive removal of oil drops from ASP flooding-produced water by polyether polysiloxane-grafted ZIF-8. Powder Technol. 2021, 378, 76-84. [CrossRef]

32. Qi, P.; Sun, D.; Gao, J.; Liu, S.; Wu, T.; Li, Y. Demulsification and bio-souring control of alkaline-surfactant-polymer flooding produced water by Gordonia sp. TD-4. Sep. Purif. Technol. 2021, 263, 118359. [CrossRef]

33. Husveg, R.; Husveg, T.; van Teeffelen, N.; Ottestad, M.; Hansen, M.R. Variable Step Size P\&O Algorithms for Coalescing Pump/Deoiling Hydrocyclone Produced Water Treatment System. Model. Identif. Control 2020, 41, $13-27$.

34. Jin, Y.; Davarpanah, A. Using photo-fenton and floatation techniques for the sustainable management of flow-back produced water reuse in shale reservoirs exploration. Water Air Soil Pollut. 2020, 231, 441. [CrossRef]

35. Simões, A.J.A.; Macêdo-Júnior, R.O.; Santos, B.L.P.; Silva, D.P.; Ruzene, D.S. A bibliometric study on the application of advanced oxidation processes for produced water treatment. Water Air Soil Pollut. 2021, 232, 297. [CrossRef]

36. Coha, M.; Farinelli, G.; Tiraferri, A.; Minella, M.; Vione, D. Advanced oxidation processes in the removal of organic substances from produced water: Potential, configurations, and research needs. Chem. Eng. J. 2021, 414, 128668. [CrossRef]

37. Hammack, R.; Mosser, M.H. Produced water management. In Coal Bed Methane; Elsevier: Amsterdam, The Netherlands, 2020; pp. 349-369.

38. Camarillo, M.K.; Stringfellow, W.T. Biological treatment of oil and gas produced water: A review and meta-analysis. Clean Technol. Environ. Policy 2018, 20, 1127-1146. [CrossRef]

39. Liu, Y.; Lu, H.; Li, Y.; Xu, H.; Pan, Z.; Dai, P.; Wang, H.; Yang, Q. A review of treatment technologies for produced water in offshore oil and gas fields. Sci. Total Environ. 2021, 775, 145485. [CrossRef]

40. Duraisamy, R.T.; Beni, A.H.; Henni, A. State of the art treatment of produced water. In Water Treatment; Books on Demand: Norderstedt, Germany, 2013, pp. 199-222.

41. Scanlon, B.R.; Reedy, R.C.; Xu, P.; Engle, M.; Nicot, J.P.; Yoxtheimer, D.; Yang, Q.; Ikonnikova, S. Can we beneficially reuse produced water from oil and gas extraction in the US? Sci. Total Environ. 2020, 717, 137085. [CrossRef]

42. Global Produced Water Treatment Industry (2021 Report). Available online: https://www.reportlinker.com/p06032674/GlobalProduced-Water-Treatment-Industry.html?utm_source=GNW (accessed on 24 October 2021).

43. The U.S. Energy Information Agency. Qatar: Oil Production. Available online: https://www.theglobaleconomy.com/Qatar/oil_ production/ (accessed on 24 October 2021).

44. Kabyl, A.; Yang, M.; Abbassi, R.; Li, S. A risk-based approach to produced water management in offshore oil and gas operations. Process Saf. Environ. Prot. 2020, 139, 341-361. [CrossRef] 
45. Santos, K.A.; Gomes, T.M.; Rossi, F.; Kushida, M.M.; Del Bianchi, V.L.; Ribeiro, R.; Alves, M.S.M.; Tommaso, G. Water reuse: Dairy effluent treated by a hybrid anaerobic biofilm baffled reactor and its application in lettuce irrigation. Water Supply 2021, 21, 1980-1993. [CrossRef]

46. Rahman, A.; Agrawal, S.; Nawaz, T.; Pan, S.; Selvaratnam, T. A review of algae-based produced water treatment for biomass and biofuel production. Water 2020, 12, 2351. [CrossRef]

47. Lahlou, F.Z.; Mackey, H.R.; McKay, G.; Onwusogh, U.; Al-Ansari, T. Water planning framework for alfalfa fields using treated wastewater fertigation in Qatar: An energy-water-food nexus approach. Comput. Chem. Eng. 2020, 141, 106999. [CrossRef]

48. Ahmad, A.Y.; Al-Ghouti, M.A. Approaches to achieve sustainable use and management of groundwater resources in Qatar: A review. Groundw. Sustain. Dev. 2020, 11, 100367. [CrossRef]

49. Kondash, A.J.; Redmon, J.H.; Lambertini, E.; Feinstein, L.; Weinthal, E.; Cabrales, L.; Vengosh, A. The impact of using low-saline oilfield produced water for irrigation on water and soil quality in California. Sci. Total Environ. 2020, 733, 139392. [CrossRef]

50. Minier-matar, J.; Hussain, A.; Janson, A.; Wang, R.; Fane, A.G.; Adham, S. Application of Forward Osmosis for Reducing Volume of Produced/Process Water from Oil and Gas Operations. Desalination 2015, 376, 1-8. [CrossRef]

51. Minier-Matar, J.; Santos, A.; Hussain, A.; Janson, A.; Wang, R.; Fane, A.G.; Adham, S. Application of Hollow Fiber Forward Osmosis Membranes for Produced and Process Water Volume Reduction: An Osmotic Concentration Process. Environ. Sci. Technol. 2016, 50, 6044-6052. [CrossRef]

52. Janson, A.; Katebah, M.; Santos, A.; Minier-Matar, J.; Hussain, A.; Adham, S.; Judd, S. Assessing the Biotreatability of Produced Water from a Qatari Gas Field. Int. Pet. Technol. 2015, 20, 1113-1119. [CrossRef]

53. Zhao, P.; Gao, B.; Xu, S.; Kong, J.; Ma, D.; Shon, H.K.; Yue, Q.; Liu, P. Polyelectrolyte-promoted forward osmosis process for dye wastewater treatment-Exploring the feasibility of using polyacrylamide as draw solute. Chem. Eng. J. 2015, 264, 32-38. [CrossRef]

54. Jansona, A.F.; Santosa, A.; Hussaina, A.; Minier-matara, J.; Juddb, S.; Adhama, S. Application of Membrane Bioreactor Technology for Produced Water Treatment. In International Gas Processing Symposium; Elsevier: Doha, Qatar, 2015.

55. Adham, S.; Hussain, A.; Matar, J.M.; Janson, A.; Gharfeh, S.; Hussain, A.; Matar, J.M.; Janson, A.; Gharfeh, S.; Adham, S. Screening of Advanced Produced Water Treatment Technologies: Overview and Testing Results Screening of Advanced Produced Water Treatment Technologies: Overview and Testing Results. IDA J. Desalin. Water Reuse 2016, 5, 7953.

56. Hussain, A.; Janson, A.; Adham, S. Treatment of Produced Water from Unconventional Resources by Membrane Distillation. In Proceedings of the Internatioal Petroleum Technoloty Conference, Doha, Qatar, 19-22 January 2014.

57. Dores, R.; Hussain, A.; Katebah, M.; Adham, S.S. Using Advanced Water Treatment Technologies to Treat Produced Water from The Petroleum Industry. In Proceedings of the SPE International Production and Operations Conference \& Exhibition, Doha, Qatar, 14-16 May 2012.

58. Zsirai, T.; Al-Jaml, A.K.; Qiblawey, H.; Al-Marri, M.; Ahmed, A.; Bach, S.; Watson, S.; Judd, S. Ceramic Membrane Filtration of Produced Water: Impact of Membrane Module. Purif. Technol. 2016, 165, 214-221. [CrossRef]

59. Zsirai, T.; Qiblawey, H.; Buzatu, P.; Al-Marri, M.; Judd, S.J. Cleaning of Ceramic Membranes for Produced Water Filtration. J. Pet. Sci. Eng. 2018, 166, 283-289. [CrossRef]

60. Abdallaa, M.; Nasser, M.; Fard, A.K.; Qiblawey, H.; Benamor, A.; Judd, S. Impact of Combined Oil-in-Water Emulsions and Particulate Suspensions on Ceramic Membrane Fouling and Permeability Recovery. Purif. Technol. 2018, 212, 215-222. [CrossRef]

61. Fard, A.K.; Mckay, G.; Atieh, M.A. Hybrid Separator -Adsorbent Inorganic Membrane for Oil-Water Separation. In Proceedings of the 3rd World Congress on Civil, Structural, and Environmental Engineering (CSEE'18), Budapest, Hungary, 8-10 April 2018; pp. 2-5.

62. Judd, S.; Qiblawey, H.; Al-Marri, M.; Clarkin, C.; Watson, S.; Ahmed, A.; Bach, S. The Size and Performance of Offshore Produced Water Oil-Removal Technologies for Reinjection. Sep. Purif. Technol. 2014, 134, 241-246. [CrossRef]

63. Qin, D.; Liu, Z.; Liu, Z.; Bai, H.; Sun, D.D. Superior Antifouling Capability of Hydrogel Forward Osmosis Membrane for Treating Wastewaters with High Concentration of Organic Foulants. Environ. Sci. Technol. 2018, 52, 1421-1428. [CrossRef]

64. Janson, A.; Santos, A.; Hussain, A.; Global, C.; Judd, S. Biotreatment of Hydrate-Inhibitor Containing Produced Waters at Low PH. SPE J. 2015, 20, 1254-1260. [CrossRef]

65. Onwusogh, U. Feasibility of Produced Water Treatment and Reuse-Case Study of a GTL. In Proceedings of the Internatioal Petroleum Technoloty Conference, Doha, Qatar, 6-9 December 2015.

66. Al Redoua, A.; Hamid, S.A.; Limited, D.E. Industrial Application for the Removal of Kinetic Hydrate Inhibitor (KHI) Co-Polymers from Produced Water Streams. In Proceedings of the International Petroleum Technology Conference, Doha, Qatar, 6-9 December 2015.

67. Moussa, D.T.; El-naas, M.H.; Nasser, M.; Al-Marri, M.J.A. Comprehensive Review of Electrocoagulation for Water Treatment: Potentials and Challenges. J. Environ. Manag. 2016, 186, 24-41. [CrossRef]

68. Aly, D.T.A. A Novel Electrocoagulation System for Produced Water Treatment. Master's Thesis, Qatar University, Doha, Qatar, 2018. Available online: http:/ /hdl.handle.net/10576/11221 (accessed on 4 December 2021).

69. Alghoul, M. Treatment of Produced Water Using an Enhanced Electrocoagulation Process. Master's Thesis, Qatar University, Doha, Qatar, 2017. 
70. Abu-dieyeh, M.H.; Shaikh, S.S.; Naemi, F.; AlAlghouti, M.; Youssef, T.A. The Influences of Produced Water Irrigation on Soil Microbial Succession and Turfgrass Grass Establishment in Qatar. In Proceedings of the Qatar Foundation Annual Research Conference, Doha, Qatar, 1 March 2018; Hamad bin Khalifa University Press: Doha, Qatar, 2018.

71. Das, P.; Abdulquadir, M.; Thaher, M.; Khan, S.; Chaudhary, A.K.; Alghasal, G.; Al-Jabri, H.M.S.J. Microalgal Bioremediation of Petroleum-Derived Low Salinity and Low PH Produced Water. J. Appl. Phycol 2019, 31, 435-444. [CrossRef]

72. Abdul Hakim, M.A. Potential Application of Micronalgea in Produced Water Treatment. Desalin. Water Treat. 2016, 135, 47-58. Available online: https:/ / qspace.qu.edu.qa:8443/bitstream/handle/10576/5087/443354_pdf_F0D5787A-36CD-11E6-9423-32BB4 D662D30.pdf?sequence $=1 \&$ isAllowed $=n$ (accessed on 4 December 2021). [CrossRef]

73. Abdul, M.A.; Al-ghouti, M.A.; Das, P.; Abu-dieyeh, M.; Ahmed, T.A.; Mohammed, H.; Aljabri, S.J. Potential Application of Microalgae in Produced Water Treatment. Desalin. Water Treat 2018, 135, 23146. [CrossRef]

74. Shaikh, S. Grass Establishment, Weed Populations and Soil Microbial Succession in Turf Grass System as Influenced by Produced Water Irrigation. Master's Thesis, Qatar University, Doha, Qatar, 2017.

75. Atia, F.A.; Al-Ghouti, M.A.; Al-Naimi, F.; Abu-Dieyeh, M.; Ahmed, T.; Al-Meer, S.H. Removal of toxic pollutants from produced water by phytoremediation: Applications and mechanistic study. J. Water Process. Eng. 2019, 32, 100990. [CrossRef]

76. Al-Kaabi, M.A.J.I. Enhancing Produced Water Quality Using Modified Activiated Carbon. Master's Thesis, Qatar University, Doha, Qatar, 2016.

77. Al-Kaabi, M.; Ghazi, A.B.; Qunnaby, R.; Dawwas, F.; Al-Hadrami, H.; Khatir, Z.; Yousif, M.; Ahmed, T. Enhancing the Quality of "Produced Water" by Activated Carbon. Qatar Found. Annu. Res. Conf. Proc. 2016, 22, 16-17.

78. Almarouf, H.M.N.; Al-Marri, M.J.; Khraisheh, M.; Onaizi, S.A. Demulsification of Stable Emulsions From Produced Water Using A Phase Separator With Inclined Parallel Arc Coalescing Plates. J. Pet. Sci. Eng. 2015, 135, 16-21. [CrossRef]

79. Benamor, A.; Talkhan, A.G.; Nasser, M.; Hussein, I.; Okonkwo, P.C. Effect of Temperature and Fluid Speed on the Corrosion Behavior of Carbon Steel Pipeline in Qatari Oilfield Produced Water. J. Electroanal. Chem. 2018, 808, 218-227. [CrossRef]

80. Shehzad, F.; Hussein, I.A.; Kamal, M.S.; Ahmad, W.; Sultan, A.S.; Nasser, M.S.; Shehzad, F.; Hussein, I.A.; Kamal, M.S.; Ahmad, W. Polymeric Surfactants and Emerging Alternatives Used in the Demulsification of Produced Water: A Review Polymeric Surfactants and Emerging Alternatives Used. Polym. Rev. 2017, 58, 63-101.

81. Ahan, J.A. Characterization of Produced Water from Two Offshore Oil Fields in Qatar; Environmental Engineering College of Engineering: Doha, Qatar, 2014. Available online: https: / qspace.qu.edu.qa/handle/10576/3287/restricted-resource?bitstreamId=0fb376 32-1e3b-4851-a058-80c438f15419 (accessed on 4 December 2021).

82. Ma, H.; Sultan, A.S.; Shawabkeh, R.; Fahd, K.; Mustafa, S. Destabilization and Treatment of Produced Water-Oil Emulsions Using Anionic Polyacrylamide with Electrolyate of Aluminum Sulphate and Ferrous Sulphate. In Proceedings of the Abu Dhabi International Petroleum Exhibition \& Conference, Abu Dhabi, United Arab Emirates, 7-10 November 2016.

83. Ray, J.P.; Engelhardt, F.R. Produced Water: Technological/Environmental Issues and Solutions; Springer Science \& Business Media: Berlin/Heidelberg, Germany, 1993.

84. Karanisa, T.; Amato, A.; Richer, R.; Abdul Majid, S.; Skelhorn, C.; Sayadi, S. Agricultural Production in Qatar's Hot Arid Climate. Sustainability 2021, 13, 4059. [CrossRef]

85. Echchelh, A.; Hess, T.; Sakrabani, R.; Prigent, S.; Stefanakis, A.I. Towards agro-environmentally sustainable irrigation with treated produced water in hyper-arid environments. Agric. Water Manag. 2021, 243, 106449. [CrossRef]

86. Hedar, Y. Pollution impact and alternative treatment for produced water. E3S Web Conf. 2018, 31, 03004.

87. Natural Gas Operation Annual Report. Available online: https://s3.amazonaws.com/rgi-documents/97e32b78209f56efc6d4ec2 ee5458fa89c264783.pdf (accessed on 23 October 2021).

88. James, L.; Ahmed, N. The Pioneer; The Public Relations Department, Qatar Gas Operating Company Limited: Doha, Qatar, 2011. Available online: https://www.qatargas.com/english/MediaCenter/ThePioneer/ThePioneer-August2011.pdf (accessed on 3 December 2021).

89. Plebon, M.J.; Saad, M.A.; Al-Kuwari, N. Application of an Enhanced Produced Water De-Oiling Technology to Middle East Oilfields. In Produced Water-Best Management Practices; TORR Canada Inc.: Montreal, QC, Canada; Qatar Petroleum: Doha, Qatar, 2007.

90. Khalifa, O.M.; Rais, T.A.M.; El Maadi, A.; Sani, R.A.; Mahrous, E.K.; Al-Marri, B. Coupling Integrated Data Management with Reservoir Surveillance Workflows for Giant Mature Field in Qatar. In Proceedings of the Internatioal Petroleum Technoloty Conference, Doha, Qatar, 6-9 December 2015.

91. Al-ghouti, M.A.; Al-kaabi, M.A.; Ashfaq, M.Y.; Adel, D. Produced Water Characteristics, Treatment and Reuse: A Review. J. Water Process Eng. 2019, 28, 222-239. [CrossRef]

92. Yaqub, A.; Isa, M.H.; Ajab, H. Electrochemical degradation of polycyclic aromatic hydrocarbons in synthetic solution and produced water using a $\mathrm{Ti} / \mathrm{SnO}_{2}-\mathrm{Sb}_{2} \mathrm{O}_{5}-\mathrm{RuO}_{2}$ anode. J. Environ. Eng. 2015, 141, 04014074. [CrossRef]

93. Macheca, A.D.; Uwiragiye, B. Application of Nanotechnology in Oil and Gas Industry: Synthesis and Characterization of Organo-modified Bentonite from Boane Deposit and its Application in Produced Water Treatment. Chem. Eng. Trans. 2020, 81, 1081-1086.

94. McLaughlin, M.C.; Borch, T.; McDevitt, B.; Warner, N.R.; Blotevogel, J. Water quality assessment downstream of oil and gas produced water discharges intended for beneficial reuse in arid regions. Sci. Total Environ. 2020, 713, 136607. [CrossRef]

95. Konur, O. Characterization and properties of biooils: A review of the research. Biodiesel Fuels 2021, 1, 137-152. 
96. Fillo, J.P.; Koraido, S.M.; Evans, J.M. Sources, characteristics, and management of produced waters from natural gas production and storage operations. In Produced Water; Springer: Boston, MA, USA, 1992; pp. 151-161.

97. Stephenson, M.T. A survey of produced water studies. In Produced Water; Springer: Boston, MA, USA, $1992 ;$ pp. 1-11.

98. Ahmad, N.A.; Goh, P.S.; Yogarathinam, L.T.; Zulhairun, A.K.; Ismail, A.F. Current advances in membrane technologies for produced water desalination. Desalination 2020, 493, 114643. [CrossRef]

99. Jacobs, R.P.W.M.; Grant, R.O.H.; Kwant, J.; Marquenie, J.M.; Mentzer, E. The composition of produced water from Shell operated oil and gas production in the North Sea. In Produced Water; Springer: Boston, MA, USA, 1992; pp. 13-21.

100. Fillo, J.P.; Evans, J.M. Characterization and Management of Produced Waters from Underground Natural Gas Storage Reservoirs. Am. Gas Assoc. Oper. Sect. Proc. 1990, 1, 448-459.

101. Healy, R.W.; Bartos, T.T.; Rice, C.A.; McKinley, M.P.; Smith, B.D. Groundwater chemistry near an impoundment for produced water, Powder River Basin, Wyoming, USA. J. Hydrol. 2011, 403, 37-48. [CrossRef]

102. Terrens, G.W.; Tait, R.D. Monitoring Ocean Concentrations of Aromatic Hydrocarbons from Produced Formation Water Discharges to Bass Strait. In Proceedings of the International Conference on Health, Society of Petroleum Engineers Australia, New Orleans, LA, USA, 6 June 1996; pp. 739-747.

103. Zhao, S.; Minier-Matar, J.; Chou, S.; Wang, R.; Fane, A.G.; Adham, S. Gas field produced/process water treatment using forward osmosis hollow fiber membrane: Membrane fouling and chemical cleaning. Desalination 2017, 402, 143-151. [CrossRef]

104. Ray, J.P.; Engelhardt, F.R. Produced Water Technological Environmental Issues and Solution. Environ. Sci. Res. 1993, 46, 96-230.

105. Dyakowski, T.; Kraipech, W.; Nowakowski, A.P.; Williams, R. A Three Dimensional Simulation of Hydrocyclone Behaviour. In Proceedings of the Second International Conference, Sydney, NSW, Australia, 9-11 November 1999; pp. $205-210$.

106. Du, Z.; Ding, P.; Tai, X.; Pan, Z.; Yang, H. Facile preparation of Ag-coated superhydrophobic/superoleophilic mesh for efficient oil/water separation with excellent corrosion resistance. Langmuir 2018, 34, 6922-6929. [CrossRef]

107. Chen, S.; Lv, C.; Hao, K.; Jin, L.; Xie, Y.; Zhao, W.; Sun, S.; Zhang, X.; Zhao, C. Multifunctional negatively-charged poly (ether sulfone) nanofibrous membrane for water remediation. J. Colloid Interface Sci. 2019, 538, 648-659. [CrossRef]

108. Wang, K.; Han, D.S.; Yiming, W.; Ahzi, S.; Abdel-Wahab, A.; Liu, Z. A windable and stretchable three-dimensional all-inorganic membrane for efficient oil/water separation. Sci. Rep. 2017, 7, 16081. [CrossRef]

109. Liu, Z. Efficient and Fast Separation of Emulsified Oil/Water Mixtures with a Novel Micro/Nanofiber Network Membrane. In Proceedings of the Qatar Foundation Annual Research Conference, Doha, Qatar, 19-20 March 2018.

110. Wang, K.; Yiming, W.; Saththasivam, J.; Liu, Z. A flexible, robust and antifouling asymmetric membrane based on ultra-long ceramic/polymeric fibers for high-efficiency separation of oil/water emulsions. Nanoscale 2017, 9, 9018-9025. [CrossRef]

111. Lee, S.; Boo, C.; Elimelech, M.; Hong, S. Comparison of fouling behavior in forward osmosis (FO) and reverse osmosis (RO). J. Membr. Sci. 2010, 365, 34-39. [CrossRef]

112. Chen, S.; Li, L.; Zhao, C.; Zheng, J. Surface hydration: Principles and applications toward low-fouling/nonfouling biomaterials. Polymer 2010, 51, 5283-5293. [CrossRef]

113. Qin, D.; Liu, Z.; Bai, H.; Sun, D.D. Three-dimensional architecture constructed from a graphene oxide nanosheet-polymer composite for high-flux forward osmosis membranes. J. Mater. Chem. A 2017, 5, 12183-12192. [CrossRef]

114. Minier-Matar, J.; Hussain, A.; Santos, A.; Janson, A.; Wang, R.; Fane, A.G.; Adham, S. Advances in Application of Forward Osmosis Technology for Volume Reduction of Produced/Process Water from Gas-Field Operations. In Proceedings of the International Petroleum Technology Conference, Doha, Qatar, 6-9 December 2015.

115. Awad, A.M.; Jalab, R.; Nasser, M.S.; El-Naas, M.; Hussein, I.A.; Minier-Matar, J.; Adham, S. Evaluation of cellulose triacetate hollow fiber membrane for volume reduction of real industrial effluents through an osmotic concentration process: A pilot-scale study. Environ. Technol. Innov. 2021, 24, 101873. [CrossRef]

116. Sosa-Fernandez, P.A.; Post, J.W.; Ramdlan, M.S.; Leermakers, F.A.M.; Bruning, H.; Rijnaarts, H.H.M. Improving the performance of polymer-flooding produced water electrodialysis through the application of pulsed electric field. Desalination 2020, 484, 114424. [CrossRef]

117. Sosa-Fernandez, P.A.; Post, J.W.; Leermakers, F.A.M.; Rijnaarts, H.H.M.; Bruning, H. Removal of divalent ions from viscous polymer-flooding produced water and seawater via electrodialysis. J. Membr. Sci. 2019, 589, 117251. [CrossRef]

118. Kumar, P.; Mitra, S. Challenges in Uninterrupted Production and Supply of Gas to Mega LNG Trains. In Proceedings of the Internatioal Petroleum Technology Conference, Doha, Qatar, 20-22 January 2014.

119. Adham, S.; Gharfeh, S.; Hussain, A.; Minier-Matar, J.; Janson, A. Kinetic Hydrate Inhibitor Removal by Physical, Chemical and Biological Processes. In Proceedings of the Offshore Technology Conference-Asia, Kuala Lumpur, Malaysia, 18 March 2014.

120. Cobham, A.; Way, H. The treatment of oily water by coalescing. Filtr. Sep. 1992, 29, 295-300.

121. Al-Shamrani, A.A.; James, A.; Xiao, H. Destabilisation of oil-water emulsions and separation by dissolved air flotation. Water Res. 2002, 36, 1503-1512. [CrossRef]

122. Al-Ghouti, M.A.; Al-Degs, Y.S.; Khalili, F.I. Minimisation of organosulphur compounds by activated carbon from commercial diesel fuel: Mechanistic study. Chem. Eng. J. 2010, 162, 669-676. [CrossRef]

123. Al-Kaabi, M.A.; Al-Ghouti, M.A.; Ashfaq, M.Y.; Ahmed, T.; Zouari, N. An integrated approach for produced water treatment using microemulsions modified activated carbon. J. Water Process. Eng. 2019, 31, 100830. [CrossRef]

124. Upadhyayula, V.K.; Deng, S.; Mitchell, M.C.; Smith, G.B. Application of carbon nanotube technology for removal of contaminants in drinking water: A review. Sci. Total Environ. 2009, 408, 1-13. [CrossRef] [PubMed] 
125. Ali, A.; Ali, K.; Kwon, K.R.; Hyun, M.T.; Choi, K.H. Electrohydrodynamic atomization approach to graphene/zinc oxide film fabrication for application in electronic devices. J. Mater. Sci. Mater. Electron. 2014, 25, 1097-1104. [CrossRef]

126. Fard, A.K.; Rhadfi, T.; Mckay, G.; Al-marri, M.; Abdala, A.; Hilal, N.; Hussien, M.A. Enhancing oil removal from water using ferric oxide nanoparticles doped carbon nanotubes adsorbents. Chem. Eng. J. 2016, 293, 90-101. [CrossRef]

127. Rasool, K.; Pandey, R.P.; Rasheed, P.A.; Buczek, S.; Gogotsi, Y.; Mahmoud, K.A. Water treatment and environmental remediation applications of two-dimensional metal carbides (MXenes). Mater. Today 2019, 30, 80-102. [CrossRef]

128. Ihsanullah, I. MXenes (two-dimensional metal carbides) as emerging nanomaterials for water purification: Progress, challenges and prospects. Chem. Eng. J. 2020, 388, 124340. [CrossRef]

129. Fard, A.K.; Mckay, G.; Chamoun, R.; Rhadfi, T.; Preud'Homme, H.; Atieh, M.A. Barium removal from synthetic natural and produced water using MXene as two dimensional (2-D) nanosheet adsorbent. Chem. Eng. J. 2017, 317, 331-342. [CrossRef]

130. Strømgren, T.; Sørstrøm, S.E.; Schou, L.; Kaarstad, I.; Aunaas, T.; Brakstad, O.G.; Johansen, O. Acute toxic effects of produced water in relation to chemical composition and dispersion. Mar. Environ. Res. 1995, 40, 147-169. [CrossRef]

131. Das, P.; Thaher, M.I.; Hakim, M.A.Q.M.A.; Al-Jabri, H.M.S.; Alghasal, G.S.H. A comparative study of the growth of Tetraselmis sp. in large scale fixed depth and decreasing depth raceway ponds. Bioresour. Technol. 2016, 216, 114-120. [CrossRef]

132. Fakhru'l-Razi, A.; Pendashteh, A.; Abdullah, L.C.; Biak, D.R.A.; Madaeni, S.S.; Abidin, Z.Z. Review of technologies for oil and gas produced water treatment. J. Hazard. Mater. 2009, 170, 530-551. [CrossRef] 